\title{
Skipan og óhæði endurskoðunarnefnda
}

\author{
Eyvindur G. Gunnarsson og Hersir Sigurgeirsson ${ }^{1}$
}

\begin{abstract}
Ágrip
Endurskoðunarnefndir gegna mikilvægu hlutverki í að tryggja áreiðanleika og óhæði endurskoðunar fyrirtækja. Eitt af meginmarkmiðum með starfsemi nefndanna er að draga úr hættu á fjármálamisferli og efla traust fjárfesta á fjárhagsupplýsingum fyrirtækja og par með fjármálamörkuðum. Í greininni eru annars vegar birtar niðurstöður rannsóknar á samsetningu endurskoðunarnefnda við einingar tengdar almannahagsmunum á Íslandi og hins vegar eru tiltekin ákvæði laga um endurskoðunarnefndir skýrð með hliðsjón af ESB-rétti. Óvissa hefur verið um túlkun ákvæða um óhæði nefndarmanna í endurskoðunarnefnd en í greininni er pað skýrt að mat á óhæði peirra er sambærilegt hefðbundnu mati á óhæði stjórnarmanna. Sér í lagi geta stjórnarmenn talist óháðir einingunni í skilningi laganna og par með skipað meirihluta endurskoðunarnefndar. Á Íslandi er algengt að stjórn skipi einn eða fleiri nefndarmenn utan stjórnar í endurskoðunarnefnd og eru nefndarmenn utan stjórnar í 63 af 70 endurskoðunarnefndum. Ekki er gert ráð fyrir pessu fyrirkomulagi í ESB-rétti eða lögum annarra Norðurlanda. Í greininni eru færð rök fyrir pví að hin íslenska framkvæmd veiki bæði sjálfstæði og umboð nefndarmanna. Æskilegt er að endurskoðunarnefnd sé eingöngu skipuð stjórnarmönnum, ef pess er kostur, en rétt er pó að innleiða í lög heimild til að hluthafafundur tilnefni nefndarmenn, eins og ESB-réttur gerir ráð fyrir. Ekki er starfandi endurskoðunarnefnd í 32 einingum tengdum almannahagsmunum. Innleiða ætti í lög, eða skýra betur, undanpáguheimildir frá starfrækslu endurskoðunarnefndar, sérstaklega að pví er varðar dótturfélög, verðbréfasjóði og sveitarfélög.
\end{abstract}

\begin{abstract}
Audit committees play a fundamental role in ensuring the integrity and quality of auditing and reporting procedures. One of the main objectives of requiring audit committees of public-interest entities is to prevent or mitigate the risk of corporate fraud and enhance investor confidence in financial reports, and thereby support the function of securities markets. We examine the composition of audit committees within public-interest entities in Iceland in the context of Icelandic legislation and evaluate the national implementation of the relevant clauses of EU law. Since the introduction of the Icelandic law, different interpretations of the requirement of
\end{abstract}

1 Eyvindur G. Gunnarsson er prófessor við lagadeild Háskóla Íslands. Hann er formaður ráðgjafarnefndar Fjármálaeftirlits Seðlabanka Íslands um hæfi stjórnarmanna fjármálafyrirtækja, vátryggingafélaga, vátryggingamiðlana og lífeyrissjóða. Netfang: egg@hi.is. Hersir Sigurgeirsson er dósent við viðskiptafræðideild Háskóla Íslands. Hann situr jafnframt í stjórn Eikar fasteignafélags hf. og er formaður endurskoðunarnefndar félagsins. Netfang: hersir@hi.is.

This work is licensed under a Creative Commons Attribution 4.0 License.

DOI: https://doi.org/10.24122/tve.a.2021.18.1.5

(C) Tímarit um viðskipti og efnahagsmál

www.efnahagsmal.is 
independence of audit committee members have surfaced. We, however, conclude that the assessment of the independence of committee members is parallel to the conventional assessment of the independence of board members. In particular, Board members can be ruled as independent by the law and can thus serve as the majority of the audit committee. In Iceland the Board of Directors usually assigns one or more non-board members to the audit committee. Such external members now serve in 63 out of 70 audit committees of public-interest entities. This arrangement is not in line with EU law nor legislation in other Nordic countries. In this article we argue that the Icelandic practice undermines the independence of committee members and weakens their mandate. The audit committee should ideally be composed solely of board members, if possible. However, to accommodate those instances when that is not possible, we recommend amending Icelandic law to allow shareholders to directly nominate committee members, in line with EU law. A total of 32 public-interest entities in Iceland do not have an audit committee. Exemptions from the operation of the audit committee should be introduced into law, or the lack thereof clarified, especially for subsidiaries, mutual funds and municipalities.

JEL flokkun: K22; M42

Lykilorð: Endurskoðun; endurskoðunarnefnd; óhæði; eining tengd almannahagsmunum

Keywords: Audit; audit committee; independence; public-interest entity.

\section{Audit committees: nomination and independence}

\section{Inngangur}

Tilvist endurskoðunarnefnda fyrirtækja má rekja a.m.k. allt aftur til fyrri hluta 19. aldar en pær hafa fengið aukið vægi undanfarin ár eftir viðamikil bókhaldsmisferli í Bandaríkjunum í upphafi pessarar aldar, m.a. hjá fyrirtækjunum WorldCom, Enron og Tyco. Misferlin, og áhrif peirra á fjármálamarkaði, leiddu til gagngerrar endurskoðunar bandarískrar löggjafar um stjórnarhætti og endurskoðun fyrirtækja sem varða almannahagsmuni sem endaði með setningu Sarbanes-Oxley laganna svonefndu árið 2002. Með lögunum var m.a. starfræksla endurskoðunarnefndar gerð lögbundin fyrir slík fyrirtæki. Tilgangurinn var að auka áreiðanleika og tryggja óhæði endurskoðunar peirra með pað að markmiði að minnka hættu á fjármálamisferlum og auka traust fjárfesta á fjárhagsupplýsingum fyrirtækjanna, sem hafði beðið mikinn hnekki eftir misferlin.

Árið 2004 gáfu Verslunarráð Íslands, Kauphöll Íslands og Samtök atvinnulífsins út leiðbeiningar um stjórnarhætti fyrirtækja par sem fjallað var um starfrækslu endurskoðunarnefndar sem hluta af góðum stjórnarháttum. Par voru gefnar leiðbeiningar um skipun nefndarinnar, val nefndarmanna og hlutverk hennar. I kjölfar útgáfu leiðbeininganna hófu fjölmörg íslensk hlutafélög starfrækslu endurskoðunarnefndar.

Í ársbyrjun 2009 var svo íslenskum aðilum sem varða hagsmuni almennings gerð skylda аð lögum að starfrækja slíka nefnd. Lögbundið hlutverk nefndarinnar er annars vegar eftirlitshlutverk með vinnuferli við gerð reikningsskila, fyrirkomulagi og virkni innra eftirlits, innri endurskoðun, áhættustýringu, endurskoðun ársreiknings og samstæðureiknings og með störfum endurskoðanda og hins vegar að meta óhæði endurskoðanda og setja fram tillögu til stjórnar um val á endurskoðanda. Sérstök ákvæði eru í lögum um óhæði og hæfni nefndarmanna. Nefndarmenn skulu vera óháðir endurskoðanda lögaðilans og meirihluti jafnframt óháður einingunni. Pá skulu peir hafa pekkingu og reynslu í samræmi við störf nefndarinnar og að minnsta kosti einn nefndarmaður skal hafa staðgóða pekkingu og reynslu á sviði reikningsskila eða endurskoðunar (Lög um breyting á lögum nr. 3/2006 um ársreikninga nr. 80/2008). 
Verkefni endurskoðunarnefndar falla undir verksvið stjórnar og er nefndin pannig undirnefnd stjórnar sem ber, eftir sem áður, endanlega ábyrgð á peim verkefnum sem nefndinni eru falin. Tilgangur pess að skipa sérstaka undirnefnd um pessi verkefni er einkum tvípættur, annars vegar að tryggja að verkefnin fái nánari athygli, umfjöllun og greiningu og hins vegar að að tryggja að pau fái umfjöllun án viðveru framkvæmdastjóra og í hópi sem er óháður bæði endurskoðanda og daglegum stjórnendum.

Allt frá setningu laganna hafa fræðimenn, eftirlitsaðilar, markaðsaðilar og aðrir sem fjallað hafa um málið ekki verið á einu máli um hvernig túlka beri tiltekin ákvæði laganna eins og rakið er í kafla 2. Einkum er par um að ræða ákvæði um óhæði nefndarmanna, skilyrði um hæfni peirra og hvort peir skuli koma úr röðum stjórnarmanna að hluta eða öllu leyti. Pá eru áhöld um hvort tilteknar einingar sem varða almannahagsmuni séu undanpegnar skyldu til að starfrækja endurskoðunarnefnd.

Stór hluti peirra íslensku aðila sem ber lagaskylda til starfrækslu endurskoðunarnefndar hefur komið slíkri nefnd á laggirnar. Í lögum er stjórn falin ábyrgð á skipun nefndarinnar (Lög um ársreikninga nr. 3/2006, 108. gr.) og í kafla 4.3 er sýnt að sú venja hefur skapast að stjórn skipi einn eða fleiri nefndarmann utan stjórnar í nefndina og jafnvel pannig að enginn stjórnarmaður eigi sæti í henni. Rakið er í kafla 3.5 að pessi venja virðist ekki vera í samræmi við texta peirra tilskipana sem íslensk lög byggjast á eða norrænan rétt í pessum efnum eins og greinir í kafla 3.3. Líkleg skýring á pessari venju er framangreind óvissa um túlkun laganna.

Tilangur pessarar greinar er í fyrsta lagi að skýra framangreind ákvæði íslenskra laga um endurskoðunarnefndir, einkum um skipun, óhæði og hæfni nefndmarmanna, m.a. með hliðsjón af ESB-rétti, og par með draga úr fyrrnefndri óvissu um túlkun laganna. Í öðru lagi eru í greininni birtar niðurstöður rannsóknar á samsetningu endurskoðunarnefnda í einingum tengdum almannahagsmunum á Íslandi par sem m.a. framangreind venja er staðfest. Í priðja lagi er fjallað um hvernig venjan samræmist íslenskum og ESBrétti og, með hliðsjón af venjum á íslenskum markaði, settar fram tillögur að lagabreytingum til að aðlaga íslenskan rétt betur að ESB-rétti.

Greinin er pannig upp byggð að fyrst er fjallað um fyrri rannsóknir á sviðinu. Pví næst er farið yfir helstu lagaákvæði sem gilda um skipan endurskoðunarnefnda í íslenskum rétti, ESB-rétti og á öðrum Norðurlöndum og framangreind lagaákvæði skýrð. Pá eru birtar niðurstöður rannsóknar á samsetningu endurskoðunarnefnda í einingum tengdum almannahagsmunum á Íslandi og að lokum eru helstu niðurstöður greinarinnar settar fram.

\section{Fyrri rannsóknir}

Margar rannsóknir hafa verið gerðar á starfsháttum og lagaumhverfi endurskoðunarnefnda á Íslandi á undanförnum áratug og er hér farið yfir helstu niðurstöður peirra sem varða efni pessarar greinar. Eins og nefnt var í inngangi greinarinnar hafa fræðimenn, eftirlitsaðilar og markaðsaðilar ekki verið á einu máli hvernig túlka beri ákvæði laga um óhæði og skipun nefndarmanna og eru niðurstöður sumra fyrri rannsókna pvert á niðurstöður pessarar greinar.

Elmar Hallgríms Hallgrímsson (2011) ritaði meistaraprófsritgerð um starfshætti endurskoðunarnefnda. Helstu niðurstöður hans voru að endurskoðunarnefndir hafi haft jákvæð áhrif á starfshætti íslenskra fyrirtækja ef pær eru skipaðar nefndarmönnum sem hafa viðeigandi pekkingu og reynslu. Pá telur hann vert að athuga hvort eðlilegt sé að lögbinda pað skilyrði að utanaðkomandi sérfræðingur eigi sæti í endurskoðunarnefnd. Slíkt ákvæði væri vandkvæðum bundið að mati greinarhöfunda par sem ESB-réttur gerir ekki ráð fyrir peim möguleika nema jafnframt væri kveðið á um að utanaðkomandi sérfræðingurinn væri kjörinn af hluthafafundi.

Einar Guðbjartsson (2011) fjallaði um merkingu hugtaksins „óháður einingunni“ sem tiltekið er í 108 gr. a laga um ársreikninga að skuli eiga við um meirihluta nefndarmanna endurskoðunarnefndar. Ekki er sett fram einhlít niðurstaða um merkingu hugtaksins í 
greininni en Einar segir vafa getið leikið á að gagnrýnin umræða geti orðið milli endurskoðunarnefndar og stjórnar um ákveðin atriði varðandi reikningsskil, endurskoðun og innra eftirlit ef allir nefndarmenn eru einnig stjórnarmenn. Niðurstaða hans virðist pví vera sú að nefndin skuli ekki eingöngu vera skipuð stjórnarmönnum sem er pvert á niðurstöður pessarar greinar.

Fjármálaeftirlitið (2011) fjallaði um skipan og störf endurskoðunarnefnda eftirlitsskyldra aðila í umræðuskjali um drög að leiðbeinandi tilmælum sem eftirlitið gaf út í júní árið 2011. Í skjalinu segist Fjármálaeftirlitið líta svo á að hugtakið „óháður einingunni“ í 108. gr. laga um ársreikninga feli m.a. í sér að viðkomandi sé ekki stjórnarmaður. Par sem meirihluti nefndarmanna skal vera óháður einingunni hefði pessi túlkun eftirlitsins falið í sér að meirihluti nefndarmanna skyldi vera skipaður nefndarmönnum utan stjórnar. Pessi túlkun laganna er pvert á niðurstöður pessarar greinar og í kafla 3.4 er fjallað rækilega um hvers vegna hún stenst ekki. Fjármálaeftirlitið felldi síðar skjalið úr gildi og pað varð ekki að leiðbeinandi tilmælum.

Einar Guðbjartsson og Jón Snorri Snorrason (2013) fjölluðu um starfsumhverfi og umfang endurskoðunarnefnda á Íslandi og birtu niðurstöður rannsóknar sinnar frá árinu 2012 á samsetningu endurskoðunarnefnda, hversu miklum tíma pær verja í nefndarstörf og menntun nefndarmanna. Helstu niðurstöður rannsóknarinnar voru að minnihluti nefndarmanna endurskoðunarnefnda taldi að tilvist endurskoðunarnefnda myndi auka traust á fjármálamarkaði meðal fjárfesta og almennings. Nefndarmenn höfðu almennt góða pekkingu á viðskiptum og fjármálum en lítill hluti peirra hafði marktæka reynslu af reikningsskilum og endurskoðun. Pá var vinnuframlag nefndarmanna að meðaltali um 40 tímar á ári.

Einar Guðbjartsson og Jón Snorri Snorrason (2017) birtu niðurstöður sambærilegrar rannsóknar sem framkvæmd var á árinu 2016 og báru pær saman við niðurstöður rannsóknarinnar frá árinu 2012. Helstu niðurstöður rannsóknarinnar voru að breytingar hafi orðið á vissum páttum í starfsumhverfi endurskoðunarnefnda. Í könnuninni árið 2016 taldi meirihluti nefndarmanna, eða 60\%, að tilkoma endurskoðunarnefnda jyki traust á fjárhagsupplýsingum meðal fjárfesta og almennings. Sérpekking nefndarmanna á fjármálum, lögum og reikningsskilum jókst miðað við könnunina 2012 en sérpekking á endurskoðun minnkaði.

Einar Guðbjartsson, Jón Snorri Snorrason og Eypór Ívar Jónsson (2018) skoðuðu samsetningu endurskoðunarnefnda m.t.t. markvirkni út frá umboðskenningunni með pví að skoða fjölbreytni, sérfræðipekkingu og óhæði nefndarmanna. Rannsókn peirra byggði á framangreindum könnunum Einars Guðbjartssonar og Jóns Snorra Snorrasonar frá árunum 2012 og 2016. Helstu niðurstöður rannsóknarinnar voru að fjölbreytni og sérfræðipekking endurskoðunarnefnda á Íslandi væri viðunandi og að samsetning nefndanna stuðlaði að markvirkni peirra.

\section{Lagaumhverfi endurskoðunarnefnda}

\subsection{Endurskoðunarnefndir í íslenskum rétti}

Ákvæði um endurskoðunarnefndir er að finna í IX. kafla A í lögum um ársreikninga nr. 3/2006 (108. gr. a - d) eins og peim var breytt með lögum nr. 80/2008, um breyting á lögum um ársreikninga. Reglurnar varða skipun endurskoðunarnefnda við einingar tengdar almannahagsmunum, hlutverk peirra, tillögu um tilnefningu endurskoðanda og um óhæði endurskoðanda og skriflega skýrslu hans um mikilvæg atriði við endurskoðunina.

Hugtakið eining tengd almannahagsmunum (e. public-interest entity) var fyrst lögfest hér á landi í eldri lögum um endurskoðendur nr. 79/2008 en með lögunum voru tekin upp ákvæði tilskipunar 2006/43/EB. Af lögskýringargögnum er ljóst að átt er við einingu sem almennt má telja pjóðhagslega mikilvæga og rétt pykir að gera auknar kröfur til um áreiðanleika og óhæði á endurskoðun (Frumvarp til laga um endurskoðendur). Hugtakið 
er nú skilgreint bæði í 3. tölul. 2. gr. laga um endurskoðendur og endurskoðun nr. 94/2019 og í 9. tölul. 2. gr. laga um ársreikninga nr. 3/2006. Eru einingar tengdar almannahagsmunum pessar:

a. Lögaðili sem er með skráð lögheimili á Íslandi og hefur verðbréf sín skráð á skipulegum verðbréfamarkaði í ríki innan EES, í aðildarríki EFTA eða í Færeyjum.

b. Lífeyrissjóður sem hefur fullgilt starfsleyfi.

c. Lánastofnun eins og hún er skilgreind í lögum um fjármálafyrirtæki.

d. Félag sem hefur starfsleyfi til að reka vátryggingastarfsemi hér á landi samkvæmt lögum um vátryggingastarfsemi.

Hlutverk endurskoðunarnefndar, samkvæmt 108. gr. b laga um ársreikninga, er m.a. eftirfarandi, án tillits til ábyrgðar stjórnar, stjórnenda eða annarra á pessu sviði: (1) Eftirlit með vinnuferli við gerð reikningsskila, (2) eftirlit með fyrirkomulagi og virkni innra eftirlits einingarinnar, innri endurskoðun, ef við á, og áhættustýringu, (3) eftirlit með endurskoðun ársreiknings og samstæðureiknings einingarinnar, (4) mat á óhæði endurskoðanda eða endurskoðunarfyrirtækis og eftirlit með öðrum störfum endurskoðanda eða endurskoðunarfyrirtækis og (5) setja fram tillögu til stjórnar um val á endurskoðanda eða endurskoðunarfyrirtæki. Einnig skal tillaga stjórnar um tilnefningu endurskoðanda eða endurskoðunarfyrirtækis byggjast á tilmælum frá endurskoðunarnefndinni, sbr. 108. gr. c. Loks skal endurskoðandi eða endurskoðunarfyrirtæki árlega gera endurskoðunarnefnd grein fyrir störfum sínum og óhæði og skila skriflegri skýrslu um mikilvæg atriði sem fram hafa komið við endurskoðunina en í skýrslunni skal sérstaklega geta um veikleika í innra eftirliti í vinnuferli við gerð reikningsskila, sbr. 108. gr. d. laganna.

Framangreind ákvæði (108. gr. b - d) eru fremur auðskýrð. Aftur á móti hafa skýringar á 108. gr. a laganna um skipun, hæfni og óhæði endurskoðunarnefnda verið á reiki. Ákvæðið hljóðar orðrétt svo:

Við einingu tengda almannahagsmunum skal starfa endurskoðunarnefnd.

Stjórn einingar ber ábyrgð á skipun endurskoðunarnefndar. Hún skal skipuð premur mönnum hið minnsta eigi síðar en mánuði eftir aðalfund.

Nefndarmenn skulu vera óháðir endurskoðanda eða endurskoðendum einingarinnar og meiri hluti nefndarmanna skal jafnframt vera óháður einingunni. Framkvæmdastjóri viðkomandi einingar skal ekki eiga sæti í nefndinni. Nefndarmenn skulu hafa pekkingu og reynslu í samræmi við störf nefndarinnar og skal að minnsta kosti einn nefndarmanna hafa staðgóða pekkingu og reynslu á sviði reikningsskila eða endurskoðunar.

Ekki er kveðið skýrt á um pað hvort nefndarmenn skuli allir koma úr röðum stjórnarmanna. Pá er ekki gert ráð fyrir peim möguleika að hluthafar geti tilnefnt nefndarmenn að hluta eða öllu leyti heldur segir pað eitt að stjórn beri ábyrgð á skipun endurskoðunarnefndar. Meginálitamálið er pó hvað felist í peim orðum greinarinnar að „,meiri hluti nefndarmanna [skuli] jafnframt vera óháður einingunni. “ Í lögunum er ekki að finna frekari skýringar á pví hvenær nefndarmaður telst „óháður einingunni.“ Í athugasemdum frumvarps pess sem varð að lögum nr. 80/2008, um breyting á lögum nr. 3/2006 um ársreikninga, er ekki að finna neina frekari leiðsögn í pessum efnum. Engu að síður er ljóst að ætlun löggjafans var að tryggja lögleiðingu á tilskipun 2006/43/EB (Frumvarp til laga um breyting á lögum um ársreikninga).

Einn megintilgangur pessarar greinar er að skýra nánar pessi ákvæði laganna, p.e. hve- 
nær nefndarmaður telst óháður einingunni, hvort nefndarmenn skuli allir koma úr röðum stjórnarmanna og hvort rétt sé að heimila hluthöfum að tilnefna nefndarmenn að hluta eða öllu leyti. Í pessu sambandi er pess að gæta að pegar um er að ræða reglur í íslenskum rétti sem ætlað er að innleiða EES-reglur í landsrétt ber að túlka pær til samræmis við viðkomandi EES-reglur. Pessi skylda, sem nefnd hefur verið meginreglan um samræmda EES-túlkun, hvílir m.a. á öllum handhöfum ríkisvalds. (Páll Hreinsson, 2014, bls. 278-280; Róbert R. Spanó, 2019, bls. 253). Af pessu leiðir að við skýringu á 108. gr. a verður að horfa til ESB-réttar. Hér á eftir verða pví réttarreglur ESB-réttar teknar til skoðunar. Að pví búnu verður varpað ljósi á pað hvernig skýra beri ákvæði íslenskra laga um skipun og óhæði nefndarmanna í endurskoðunarnefnd.

\subsection{ESB/EES-réttur}

Frá gildistöku EES-samningsins hinn 1. janúar 1994 hafa fjölmargar tilskipanir og reglugerðir ESB verið innleiddar í íslenskan rétt, par á meðal um endurskoðun. Með tilskipun 78/660/EBE voru í fyrsta sinn innleiddar kröfur um endurskoðun reikningsskila fyrirtækja með takmarkaðri ábyrgð. Með tilskipun 84/253/EBE um löggildingu einstaklinga sem falið er að annast löggilta endurskoðun bókhaldsgagna voru svo innleiddar kröfur sem gera purfti til hæfis endurskoðenda, einkum um menntun og starfspjálfun. Árið 1998 var komið á fót sérstakri nefnd í peim tilgangi að vinna að samræmingu reglna um reikningsskil og endurskoðun innan ESB (98/C 143/03). Afrakstur peirrar vinnu var tilskipun 2006/43/EB um lögboðna endurskoðun ársreikninga og samstæðureikninga en tilskipunin sótti fyrirmynd sína til Bandaríkjanna par sem sett voru lög árið 2002 (Sarbanes-Oxley Act) í kjölfar áđurnefndra fjármálamisferla par í landi kennd við Enron, WorldCom og Tyco. Sú tilskipun lagði grunninn að gildandi reglum um endurskoðun og endurskoðendur. Markmiðið var að gera lágmarkskröfur sem ætlað var að sporna við fjármálamisferli og tryggja betur að hagsmunaaðilar gætu reitt sig á störf endurskoðenda (Frumvarp til laga um endurskoðendur).

Eftir fjármálakreppuna 2008 birti Framkvæmdastjórn ESB (2010) grænbók par sem tekið var til skoðunar hvort nauðsyn væri á umbótum á lögum og reglum um endurskoðun til að styrkja fjármálastöðugleika. Í framhaldi af peirri vinnu voru sampykktar nýjar reglur hinn 16. apríl 2014, annars vegar tilskipun 2014/56/ESB um breytingu á tilskipun 2006/43/EB um lögboðna endurskoðun ársreikninga og samstæðureikningsskila og hins vegar reglugerð 2014/537/ESB um sérstakar kröfur í tengslum við lögboðna endurskoðun á einingum tengdum almannahagsmunum. Með tilvitnaðri reglugerð eru gerðar auknar kröfur til endurskoðunar á einingum tengdum almannahagsmunum, auk pess sem hún mælir fyrir um aukin verkefni endurskoðunarnefnda.

Í tilskipun 2006/43/EB var að finna fyrstu ákvæðin um endurskoðunarnefndir innan ESB. Í 24. formálsorðum tilskipunarinnar er hlutverki endurskoðunarnefndar lýst. Par segir m.a. að mikilvægt sé að efla óhæði og tæknilega getu endurskoðunarnefndar með pví að gera pá kröfu að meirihluti nefndarmanna sé óháður og að a.m.k. einn nefndarmaður sé bær til að sinna endurskoðun og/eða bókhaldi. Um skipun og störf endurskoðunarnefnda er vísað til tilmæla framkvæmdastjórnarinnar frá 15. febrúar 2005 (2005/162/EB) um hlutverk stjórnarmanna, sem eru ekki framkvæmdastjórar, eða eftirlitsstjórnarmanna í skráðum félögum svo og um stjórnarnefndir (eftirlitsstjórnarnefndir) félaga (Stjórnartíðindi Evrópusambandsins, 2005, bls. 51). Pá segir að stjórn í heild geti sinnt peim verkefnum sem falin eru endurskoðunarnefnd í litlum og meðalstórum einingum tengdum almannahagsmunum. Einnig kemur fram að verðbréfasjóðir eða sérhæfðir sjóðir, sem eru einingar tengdar almannahagsmunum, skuli vera undanpegnir skyldu til að hafa endurskoðunarnefnd. Í 25. formálsorðum tilskipunarinnar er svo vikið að undanpáguheimild fyrirtækja um sameiginlega fjárfestingu (UCITS) frá kröfunni um að hafa endurskoðunarnefnd.

Í X. kafla tilskipunar 2006/43/EB voru sérákvæði vegna lögboðinnar endurskoðunar 
eininga tengdra almannahagsmunum. Kaflinn var felldur úr gildi með tilskipun 2014/56/ ESB og nýjar reglur um sama efni settar í reglugerð 2014/537/ESB. Ákvæði um skyldu til að skipa endurskoðunarnefnd í einingum tengdum almannahagsmunum er pó áfram að finna í tilskipun 2006/43/ESB en í nokkuð breyttri mynd. Ekki er um mikla efnisbreytingar að ræða. Regluna var áður að finna í 41. gr. en hún er nú í 39. gr.

Hér er lögð áhersla á að lýsa peim kröfum sem gerðar eru til skipunar endurskoðunarnefnda og hæfni og óhæðis nefndarmanna ásamt undanpáguheimildum frá starfrækslu nefndarinnar. Umfjöllun um önnur ákvæði, sem varða fyrst og fremst verkefni endurskoðunarnefnda, er að mestu látin liggja milli hluta.

Par sem IX. kafli laga um ársreikninga tekur mið af tilskipun 2006/43/EB, áður en henni var breytt með tilskipun 2014/56/ESB, er rétt að rekja efni fyrri undirmálsgreinar 1. mgr. 41. gr. tilskipunar 2006/43/EB, sem skyldaði einingar tengdum almannahagsmunum að hafa endurskoðunarnefnd:

Öll fyrirtæki sem varða hagsmuni almennings skulu hafa endurskoðunarnefnd. Aðildarríki skal ákvarða hvort endurskoðunarnefndir skulu skipaðar stjórnarmönnum sem ekki eru framkvæmdastjórar, og/eða stjórnarmönnum í eftirlitsstjórn aðilans sem er endurskoðaður og/eða fulltrúum sem eru tilnefndir á hluthafafundi aðilans sem er endurskoðaður. Аð minnsta kosti einn nefndarmaður í endurskoðunarnefndinni skal vera óháður og skal hafa menntun og hæfi á sviði reikningsskila og/eða endurskoðunar.

Ofanritað ber með sér að samkvæmt eldri reglu voru tveir möguleikar um skipun nefndarmanna í endurskoðunarnefnd; annað hvort að peir kæmu úr hópi stjórnarmanna eða væru utan stjórnar og pá skipaðir af hluthafafundi. Einn nefndarmaður hið minnsta skyldi hafa pekkingu á sviði reikningsskila eða endurskoðunar. Samkvæmt 24. formálsorðum með tilskipuninni skyldi meirihluti stjórnarmanna vera óháður. Reglur um endurskoðunarnefndir í lögum um ársreikninga byggjast á pessu eldra ákvæði tilskipunarinnar.

Ákvæði 39. gr. tilskipunar 2006/43/EB, sem var breytt með tilskipun 2014/56/ESB, geymir gildandi reglur um endurskoðunarnefndir á í ESB-rétti. Samkvæmt 1. mgr. gildir sú meginregla að í einingu tengdri almannahagsmunum sé endurskoðunarnefnd en einnig er kveðið á um skipun og hæfi nefndarmanna. Í 2. mgr. er að finna undantekningu frá skipun endurskoðunarnefndar í ákveðnum litlum og meðalstórum fyrirtækjum sem teljast einingar tengdar almannahagsmunum. Eins eru undantekningar í 3. mgr. frá skyldunni til skipunar endurskoðunarnefndar hjá nánar tilgreindum aðilum, sem skilgreindir eru í tilskipunum og reglugerðum ESB, en um er að ræða tiltekin dótturfélög, verðbréfasjóði, útgefendur eignatryggðra verðbréfa og smáar lánastofnanir. Pá er aðildarríkjum heimilt skv. 4. mgr. að gera undantekningu frá skyldunni um endurskoðunarnefnd ef innan einingar tengdrar almannahagsmunum er að finna aðila sem gegnir sambærilegu hlutverki, enda sé sú skipan mála í samræmi við lög viðkomandi ríkis. İ 5. mgr. er að finna undantekningu frá óhæðiskröfu 1. mgr. Loks kveður 6. mgr. á um verkefni endurskoðunarnefndar.

Meginregla 1. mgr. 39. gr. tilskipunar 2006/43/EB er nú svohljóðandi:

Aðildarríkin skulu tryggja að í sérhverri einingu tengdri almannahagsmunum sé endurskoðunarnefnd. Endurskoðunarnefndin skal annað hvort vera sjálfstæð nefnd eða nefnd stjórnar eða eftirlitsstjórnar endurskoðuðu einingarinnar. Hún skal skipuð stjórnarmönnum, sem ekki eru framkvæmdastjórar og/eða stjórnarmönnum í eftirlitsstjórn aðilans sem er endurskoðaður og/eða fulltrúum sem eru tilnefndir á hluthafafundi aðilans sem er endurskoðaður eða, að pví er varðar einingar sem ekki eru með hluthafa af peim sem gegna hliðstæðu hlutverki og hluthafafundur. 
Að minnsta kosti einn nefndarmaður í endurskoðunarnefndinni skal hafa menntun og hæfi á sviði reikningsskila og/eða endurskoðunar.

Í heild skulu nefndarmenn í endurskoðunarnefndinni hafa yfir að ráđa hæfni sem viðkemur geiranum sem endurskoðaða einingin starfar í.

Meirihluti nefndarmanna í endurskoðunarnefndinni skal vera óháður endurskoðuðu einingunni. Formaður endurskoðunarnefndarinnar skal vera skipaður af nefndarmönnum eða eftirlitsstjórn endurskoðuðu einingarinnar og skal vera óháður endurskoðuðu einingunni. Aðildarríki [mega]2 gera kröfu um að formaður endurskoðunarnefndarinnar sé kjörinn árlega á hluthafafundi endurskoðuðu einingarinnar.

Ákvæði 5. mgr. 39. gr. hljóðar svo:

Ef allir nefndarmenn í endurskoðunarnefndinni sitja í stjórn eða eftirlitsstjórn endurskoðuðu einingarinnar getur aðildarríkið kveðið svo á um að endurskoðunarnefndin sé undanpegin óhæðiskröfunum sem mælt er fyrir um í fjórðu undirgrein 1 . mgr.

Saman mynda framangreindar reglur tilskipunar 2006/43/EB, eins og henni var breytt með tilskipun 2014/56/ESB, auk 24. og 25. formálsorða, gildandi lagaramma um skipun og óhæði nefndarmanna í endurskoðunarnefndum í ESB-rétti.

Samanburður á 39. gr. tilskipunar 2006/43/EB við eldra ákvæði 41. gr. um endurskoðunarnefndir sýnir nokkrar efnisbreytingar. Mesta pýðingu fyrir pað viðfangsefni sem hér er til skoðunar hafa 1. mgr. og 5. mgr. 39. gr.

Í fyrsta lagi er berum orðum tekið fram að endurskoðunarnefnd geti hvort heldur verið sjálfstæð nefnd eða nefnd stjórnar en ráð er fyrir pví gert að hluthafafundur (eða hliðstæður vettvangur) geti skipað nefndina. Í öðru lagi er ekki lengur tekið fram á sá nefndarmaður sem býr yfir pekkingu á reikningsskilum og endurskoðun skuli vera óháður. Í priðja lagi skulu nefndarmenn í heild "hafa yfir að ráða hæfni sem viðkemur geiranum sem endurskoðaða einingin starfar i.. II fjórða lagi er nú berum orðum tekið fram (4. undirmálsgrein 1. mgr.) að meirihluti nefndarmanna í endurskoðunarnefnd skuli vera óháður einingunni en áður var pað aðeins tekið fram í 24. formálsorðum. Í fimmta lagi er vikið að formanni nefndarinnar sérstaklega. Fram kemur að annað hvort nefndarmenn eða stjórn endurskoðuðu einingarinnar skipi formann nefndarinnar sem skuli vera óháður einingunni. Pá segir að aðildarríkin megi gera kröfu um að formaður endurskoðunarnefndar sé kjörinn árlega á hluthafafundi einingarinnar.

Í 5. mgr. 39. gr. er nýmæli sem rakið var orðrétt að framan. Efnislega felur reglan í sér heimild til handa aðildarríkjum að undanpiggja endurskoðunarnefnd kröfunni um að meirihluti nefndarmanna sé óháður einingunni pegar allir nefndarmenn sitja jafnframt í stjórninni. Danmörk hefur t.d. nýtt sér pessa heimild og gerir nú ekki kröfu um óhæði meirihluta endurskoðunarnefndar (Lov om ændring af revisorloven og forskellige andre love nr. 631/2016). Hvað sem pessu líður er pó mælt með pví í leiðbeiningum um stjórnarhætti að meirihluti nefndarmanna sé óháður (Bunch og Whitt, 2018, bls. 621).

\subsection{Réttarstaða og framkvæmd á Norðurlöndum}

Til samanburðar er athyglisvert að skoða réttarstöðuna og framkvæmdina á Norðurlöndum en öll byggja pau löggjöf sína í pessum efnum á ESB-rétti.

2 Í íslenskri pýðingu tilskipunarinnar er orðið „,skulu“ ranglega notað. Samanburður við erlenda texta leiðir í ljós heimild en ekki skyldu („may“ á ensku, „kan“ á dönsku og „können“ á pýsku). 
Í norskum lögum um almenningshlutafélög kemur m.a. fram að endurskoðunarnefnd sé ráðgefandi starfsnefnd stjórnar. Stjórnin velur nefndarmenn úr röðum stjórnarmanna. Óheimilt er að velja nefndarmenn úr hópi æðstu stjórnenda einingarinnar. Ekki er sérstaklega kveðið á um óhæði nefndarmanna að öðru leyti en pví að formaður nefndarinnar skal vera óháður einingunni og hafa pekkingu á sviði reikningsskila eða endurskoðunar (Lov om aksjeselskaper nr. 45/1997, gr. 6-41 til 6-43). Í norskum leiðbeiningum um stjórnarhætti segir að til viðbótar lögfestum skilyrðum um samsetningu endurskoðunarnefndar skuli meirihluti nefndarmanna vera óháður. Í skýringum við ákvæðið er pess getið að við mat á óhæði nefndarmanna megi horfa til sömu sjónarmiða og við mat á óhæði stjórnarmanna. Einnig skuli tilnefningarnefnd, pegar hún gerir tillögur að stjórnarmönnum, hafa í huga hvaða stjórnarmenn uppfylli skilyrði um óhæði og pekkingu sem krafist er af nefndarmönnum í endurskoðunarnefnd (Norsk utvalg for eierstyring og selskapsledelse, 2018).

Í sænskum hlutafélagalögum eru ákvæði um endurskoðunarnefndir í greinum 49 a og b. Par segir m.a. að nefndarmenn megi ekki vera starfsmenn félagsins, einn nefndarmanna hið minnsta skuli hafa pekkingu á sviði reikningsskila eða endurskoðunar og að nefndin skuli skipa formann nefndarinnar úr sínum röðum. Ekki er vikið að óhæði nefndarmanna (Aktiebolagslag nr. 551/2005, gr. 49 a og b). Í sænskum leiðbeiningum um stjórnarhætti segir að meirihluti nefndarmanna skuli vera óháður félaginu og framkvæmdastjórn. Pá skuli a.m.k. einn stjórnarmanna, sem er óháður félaginu og framkvæmdastjórn pess, einnig vera óháður stærstu hluthöfum félagsins. Um mat á óhæði nefndarmanna vísa leiðbeiningarnar til peirra sjónarmiða sem gilda um mat á óhæði stjórnarmanna félagsins (Kollegiet för svensk bolagsstyrning, 2019).

Í dönskum lögum um endurskoðendur segir að endurskoðunarnefnd skuli samanstanda af mönnum sem sitja í stjórn félagsins, en eru ekki jafnframt í framkvæmdastjórn pess, mönnum sem sitja í fulltrúanefnd eða einstaklingum sem kosnir eru á hluthafafundi einingarinnar eða af sambærilegum aðila (Lov om godkendte revisorer og revisionsvirksomheder (revisorloven) nr. 468/2008, gr. 31). Áður en lögunum var breytt árið 2016 gátu aðeins stjórnarmenn eða nefndarmenn í fulltrúanefnd tekið sæti í endurskoðunarnefnd en nú er pað ekki lengur skilyrði (Lov om ændring af revisorloven og forskellige andre love nr. 631/2016). Pá er pess ekki lengur krafist að meirihluti endurskoðunarnefndar sé óháður einingunni eins og heimilt er samkvæmt 5. mgr. 39. gr. tilskipunar 2006/43/EB. Í dönskum leiðbeiningum um stjórnarhætti er pó mælt með pví að eingöngu stjórnarmenn sitji í nefndinni og að meirihluti nefndarmanna sé óháđur einingunni (Komitéen for god selskabsledelse, 2020, gr. 3.4.2).

Skoðun á skipan endurskoðunarnefnda í tíu stærstu fyrirtækjum Noregs, Svípjóðar og Danmerkur hinn 22. júlí 2021 sýnir að hjá hverju peirra var endurskoðunarnefndin skipuð að fullu nefndarmönnum úr röðum stjórnarmanna. Tafla 2 í viðauka sýnir yfirlit yfir tíu stærstu fyrirtækin í hverju landi, fjölda stjórnarmanna, fjölda nefndarmanna í endurskoðunarnefnd og fjölda nefndarmanna utan stjórnar, sem er eins og fyrr segir í hverju tilviki enginn.

\subsection{Hvernig ber að skýra ákvæði laga um óhæði?}

Fljótlega í kjölfar lögfestingar ákvæða um endurskoðunarnefndir risu álitamál um pað hvað fælist í peim áskilnaði laga um ársreikninga að meirihluti nefndarmanna skyldi vera „óháður einingunni.“ Í skýrslu nefndar um málefni endurskoðenda (2011, bls. 23-24) sagði að nefndin teldi ekki nægilega skýrt kveðið á um í lögunum hvernig endurskoðunarnefnd skyldi skipuð og væri nauðsynlegt að kveða skýrar á um pað. Pannig væri óljóst hvað átt væri við með að nefndarmenn skyldu óháðir félaginu. Petta hefði vakið upp spurningar um hvort allir nefndarmenn skyldu vera stjórnarmenn eða enginn og allt par á milli. Nefndin taldi mikilvægt að litið yrði á verkefni endurskoðunarnefnda sem hluta af verkefnum stjórnar og pví mætti ekki ýta peim út af borði stjórnar með pví að aðeins menn utan stjórnar skipuðu endurskoðunarnefnd. Par á móti birtist önnur afstaða í umræðu- 
skjali Fjármálaeftirlitsins (2011) pess efnis að stjórnarmenn einingar gætu ekki myndað meirihluta endurskoðunarnefndar hennar.

Með hliðsjón af pví að ætlunin með setningu laga nr. 80/2008, um breyting á lögum um ársreikninga, var að innleiða tilskipun 2006/43/EB verður við túlkun pess hvað átt sé við með pví að meirihluti nefndarmanna skuli vera "óháður einingunni“ í skilningi laganna að horfa til tilskipunarinnar. Par sem lög um ársreikninga og lögskýringargögn með lögum nr. 80/2008, um breyting á lögum um ársreikninga, eru hljóð um pað hvað felist í peim áskilnaði að meirihluti nefndarmanna í endurskoðunarnefnd skuli vera „óháður einingunni“ er rétt að horfa til tilmæla framkvæmdastjórnarinnar frá 15. febrúar 2005 (2005/162/ EB) enda beinlínis vísað til peirra í tilskipunni. Í lið 13.2 í tilmælunum segir að mat á óhæði hvíli á stjórninni. Рað er í samræmi við pað að stjórn ber ábyrgð á skipun endurskoðunarnefndar, sbr. 2. mgr. 108. gr. a laga um ársreikninga.

Við mat á pví hvort nefndarmaður í endurskoðunarnefnd telst óháður parf stjórn að hafa hliðsjón af íslenskum aðstæðum, m.a. félagsstjórnarkerfi íslensks hlutafélagaréttar sem gerir ráð fyrir aðskilnaði milli félagsstjórnar og framkvæmdastjórnar og banni við pví að kjósa framkvæmdastjóra félags sem stjórnarformann pess. ${ }^{3}$ Umfjöllun í tilmælum framkvæmdastjórnarinnar (2005/162/EB) um óhæði stjórnar á rætur sínar að rekja til ensks og bandarísks hlutafélagaréttar en hann er frábrugðinn norrænum og pýskum rétti hvað varðar félagsstjórn (Andersen, 2019, bls. 315).

Meginregla ensks og bandarísks réttar er sú að stjórn félags er einpátta. Í pessu felst að í félagsstjórn (board of directors), sem hluthafafundur kýs, eru bæði eftirlitspáttur og framkvæmdapáttur á sömu hendi (einpátta stjórn). Í framkvæmd gætir pó oft verkaskiptingar á milli stjórnarmanna. Sumir stjórnarmenn sinna einnig daglegri stjórnun (managing directors eða executive directors í Englandi og officers eða full-time directors í Bandaríkjunum) en aðrir eingöngu eftirlitshlutverki (ordinary eða non-executive directors í Englandi og parttime eða outside directors í Bandaríkjunum). Engu að síður sitja stjórnarmenn allir í sömu stjórninni (Stefán Már Stefánsson, 2013, bls. 290-291).

Pýskur hlutafélagaréttur gerir ráð fyrir tvískiptingu félagsstjórnar sem er mun skarpari en í norrænum rétti. Pannig kýs hluthafafundur félagsstjórn (Aufsichtsrat) en félagsstjórn ræður framkvæmdastjórnina (Vorstand). Eftirlitshlutverkið er á hendi félagsstjórnar en framkvæmdastjórnin stjórnar félaginu á eigin ábyrgð undir eftirliti félagsstjórnar. Fullkominn aðskilnaður er á milli pessara stjórnareininga enda getur enginn setið samtímis í framkvæmdastjórn og félagsstjórn (Grundmann og Glasow, 2012, bls. 255-257).

Norrænn réttur byggist á tveggja pátta félagsstjórnarkerfi og liggur á milli pýska og enska/bandaríska kerfisins. Í pví felst að félagsstjórn er eins konar yfirstjórn og hefur eftirlit með framkvæmdastjóra.

Munurinn á einpátta og tvípátta félagsstjórn birtist skýrlega í framangreindum tilmælum og tilskipunum 2006/43/EB og 2014/56/ESB. Samanburður á pýska, enska og íslenska textanum leiðir í ljós að eftirlitsstjórn er nefnd Aufsichtsrat á pýsku en supervisory board á ensku. Stjórnarmenn, sem ekki eru framkvæmdastjórar, kallast nicht geschäftsführende Direktoren á pýsku og non-executive directors á ensku. Pá nefnast eftirlitsstjórnarmenn Aufsichtsratsmitglieder á pýsku og supervisory directors á ensku.

Með hliðsjón af muninum á einpátta og tvípátta stjórnareiningum má slá pví föstu að stjórnir íslenskra eininga tengdra almannahagsmunum eru „eftirlitsstjórnir“ í skilningi tilskipana 2006/43 og 2014/56 sem og tilmæla framkvæmdastjórnarinnar (2005/162/EB) sem jafna til Aufsichtsrats í pýskum rétti og nefnt er supervisory board á ensku. ${ }^{4}$ Af pessu leiðir

3 Í tilmælum framkvæmdastjórnarinnar frá 15. febrúar 2005 (2005/162/EB) segir í lið 1.3 .1 um starfsemi stjórnarnefnda að pær "should duly take into account the rights and duties of relevant corporate bodies as defined under national law.“ Eins kemur skýrt fram í II. viðauka við tilmælin að laga skuli pau viðmið, sem nefnd séu í tilmælunum, aðstæðum í viðkomandi ríki.

4 Hér er pess að geta að í 73. gr. laga um hlutafélög nr. 2/1995 er sérstök heimild hlutafélaga til að hafa fulltrúanefnd sem skal hafa eftirlit með pví hvernig félagsstjórn og framkvæmdastjóri ráða málum félagsins og getur hún einnig talist eftirlitsstjórn í skilningi tilskipunarinnar. Afar sjaldgæft er að hlutafélög nýti 
að almenna reglan er sú að skipa ber meirihluta nefndarmanna í endurskoðunarnefndum úr röðum óháðra stjórnarmanna viðkomandi einingar tengdrar almannahagsmunum. Af pessu má jafnframt að draga pá ályktun að pað sjónarmið sem hreyft var í umræðuskjali Fjármálaeftirlitsins nr. 6/2011, að stjórnarmenn í íslenskum einingum tengdum almannahagsmunum gætu ekki myndað meirihluta endurskoðunarnefndar, er ekki í samræmi við texta framangreindra tilskipana og tilmæla.

Í II. viðauka tilmæla framkvæmdastjórnarinnar (2005/162/EB) er sagt að pau tilvik verði seint tæmandi talin sem ógnað geti óhæði stjórnarmanna í félögum. Aðstæður eða tengsl sem pýðingu hafi í pessu sambandi kunni að vera breytileg frá einu félagi eða aðildarríki til annars. Geti besta framkvæmd hverju sinni tekið breytingum í tímans rás. Pótt hafa megi tiltekin viðmið til leiðbeiningar ríki samstaða um pað að mat á óhæði einstakra stjórnarmanna eigi að byggjast á efnislegu mati fremur en formlegu („,based on substance rather than form“). Pá segir að laga skuli pau viðmið, sem nefnd séu í tilmælunum, aðstæðum í viðkomandi ríki. Í viðaukanum eru pó tilgreind níu tölusett lágmarksviðmið sem hafa skuli í huga að við mat á óhæði.

Lágmarksviðmiðin eru í meginatriðum samhljóða eftirfarandi viðmiðum um pað hvort stjórnarmaður teljist óháður félaginu og daglegum stjórnendum pess, sem sett eru fram í kafla 2.3 í Leiðbeiningum um stjórnarhætti fyrirtækja (Viðskiptaráð Íslands, Nasdaq Iceland og Samtök atvinnulífsins, 2015), en viðmiðin eru að mestu óbreytt frá fyrstu útgáfu leiðbeininganna sem gefin var út í mars 2004:

Stjórnarmaður er ekki óháður félaginu og daglegum stjórnendum pess:

1. Ef hann er eða hefur verið starfsmaður félagsins eða nátengds félags undanfarin prjú ár áður en hann tekur sæti í stjórn félagsins.

2. Ef hann piggur eða hefur pegið verulegar greiðslur frá félaginu, nátengdu félagi eða daglegum stjórnendum pess, fyrir utan stjórnarlaun, t.d. sem ráðgjafi eða verktaki, undanfarin prjú ár áður en hann tekur sæti í stjórn félagsins.

3. Ef hann er eða hefur verið síðastliðið ár, í umtalsverðum viðskiptum við félagið eða nátengd félög, t.a.m. sem viðskiptavinur, birgir eða samstarfsaðili, eða hefur mikilla annarra viðskiptahagsmuna að gæta í félaginu, hvort heldur persónulega eða í gegnum annað félag.

4. Ef hann er einn af daglegum stjórnendum annars félags par sem einn af stjórnarmönnum pess er daglegur stjórnandi í félaginu.

5. Ef hann er, eða hefur verið undanfarin prjú ár áđur en hann tekur sæti í stjórn félagsins, meðeigandi ytri endurskoðanda félagsins eða nátengds félag, eða starfsmaður sem tekið hefur pátt í ytri endurskoðun félagsins.

6. Ef hann er tengdur nánum fjölskylduböndum daglegum stjórnendum félagsins og/eða aðila sem nefndur er í töluliðunum hér að framan ef sá aðili er í beinum eða óbeinum viðskiptum við félagið og pau eru slík að umfangi að ekki er réttlætanlegt að telja stjórnarmanninn óháðan.

Eins og fyrr segir eru sömu eða mjög svipuð sjónarmið lögð til grundvallar við matið í leiðbeiningunum og framangreindum II. viðauka tilmæla framkvæmdastjórnarinnar en efnislega er helsti munurinn eftirfarandi: (1) II. viðauki tilgreinir sérstaklega að fulltrúi starfsmanna í stjórn geti talist óháður; (2) Stjórnarmenn sem hafa setið lengi teljast ekki óháðir samkvæmt II. viðauka (lengur en prjú tímabil eða 12 ár); (3) Leiðbeiningarnar horfa almennt til undanfarinna priggja ára varðandi tengsl en II. viðauki til fimm ára. Mat á pví hvort

petta ákvæði og engin íslensk eining tengd almannahagsmunum er með fulltrúanefnd. Í stjórnsýsluúttekt innri endurskoðunar Reykjavíkurborgar á Orkuveitu Reykjavíkur árið 2008 var pó bent á pann kost að skoða tilkomu fulltrúanefndar í Orkuveitunni ef félagsformi hennar væri breytt í hlutafélag (Hallur Símonarson, 2008). 
nefndarmaður endurskoðunarnefndar teljist óháður einingunni samkvæmt lögum um ársreikninga er pví sambærilegt mati á pví hvort stjórnarmaður teljist óháður félaginu og daglegum stjórnendum samkvæmt íslenskum leiðbeiningum um stjórnarhætti fyrirtækja.

Í stuttu máli má lýsa réttarstöðunni svo að 108. gr. a laga um ársreikninga geymir ekki skilgreiningu á pví hvenær nefndarmaður í endurskoðunarnefnd telst óháður einingunni. Í samræmi við meginregluna um samræmda EES-túlkun, sem áður er getið, er rökrétt að skýra hugtakið óhæði í 108. gr. a laganna með hliðsjón af tilskipun 2006/43 sem ákvæðið byggist á. Í tilskipuninni er vísað til tilmæla framkvæmdastjórnarinnar frá 15. febrúar 2005 (2005/162/EB) hvað varðar endurskoðunarnefndir. Í I. viðauka í tilmælunum segir um samsetningu endurskoðunarnefndar að hún skuli eingöngu samanstanda af stjórnarmönnum, sem eru ekki framkvæmdastjórar (non-executive), eða eftirlitsstjórnarmönnum (supervisory directors). Pá skuli a.m.k. helmingur nefndarmanna vera óháður. Í II. viðauka við tilmælin er svo aftur að finna skilgreiningu á pví hvenær stjórnarmenn eru óháðir og nær sú skilgreining m.a. til peirra stjórnarmanna sem sitja í endurskoðunarnefnd. Af pessu leiðir að skýra verður óhæði nefndarmanna í endurskoðunarnefnd með sama hætti og óhæði stjórnarmanna, svo sem gert er í Noregi og Svípjóð, eins og áður segir.

\subsection{Hvernig skal skipun nefndarmanna hagað?}

Um skipun nefndarmanna í endurskoðunarnefnd segir í lögum um ársreikninga (108. gr. a) að (1) stjórn einingar beri ábyrgð á skipun endurskoðunarnefndar, (2) hún skuli skipuð premur mönnum hið minnsta eigi síðar en mánuði eftir aðalfund, (3) nefndarmenn skuli vera óháðir endurskoðanda eða endurskoðendum einingarinnar, (4) meirihluti nefndarmanna skuli vera óháður einingunni og (5) framkvæmdastjóri einingarinnar skuli ekki eiga sæti í nefndinni.

Ekki er í lögunum sérstaklega kveðið á um hvort nefndarmenn skuli koma úr röðum stjórnarmanna að hluta eða öllu leyti. Pá er heldur ekki sérstaklega kveðið á um heimild hluthafafundar (eða hliðstæðs vettvangs) til að tilnefna nefndarmenn eins og heimild er fyrir í ESB-rétti. Eins og rakið var hér að framan kemur skilyrðið um óhæði meirihluta nefndarmanna ekki í veg fyrir að stjórnarmenn skipi a.m.k. meirihluta nefndarinnar. Eftir stendur pá spurningin um hvort heimilt sé að skipa aðila utan stjórnar í nefndina og pá með hvaða hætti skipun peirra skuli hagað.

Tilskipun 2006/43/EB, eins og henni var breytt með tilskipun 2014/56, er skýrari hvað varðar skipun nefndarmanna. I 1. mgr. 39. gr. kemur fram að nefndin skuli skipuð (1) stjórnarmönnum, sem ekki eru jafnframt framkvæmdastjórar (non-executive), og/eða (2) stjórnarmönnum í eftirlitsstjórn (supervisory directors), og/eða (3) fulltrúum sem eru tilnefndir á hluthafafundi. Tilskipunin heimilar pví að nefndarmenn komi ekki úr röðum stjórnar en peir skulu pá tilnefndir af hluthafafundi. Verður að skilja pað svo að einstaklingar, sem ekki sitja í félagsstjórn, geti pví aðeins tekið sæti í endurskoðunarnefnd að hluthafafundur standi að peirri skipun. Eins og fyrr segir er stjórn einingarinnar falin ábyrgð á skipun nefndarinnar í íslenskum lögum og skýra lagaheimild skortir pví fyrir pví að hluthafafundur komi að skipuninni. Nánar verður vikið að pessum atriðum í köflum 4.4 og 4.5 .

\subsection{Um hæfnisskilyrði nefndarmanna}

Um hæfnisskilyrði nefndarmanna í endurskoðunarnefnd segir í lögum um ársreikninga að nefndarmenn skuli hafa pekkingu og reynslu í samræmi við störf nefndarinnar. Einnig skal að minnsta kosti einn nefndarmanna hafa staðgóða pekkingu og reynslu á sviði reikningsskila eða endurskoðunar. Sú krafa laganna að nefndarmenn búi saman yfir pessari sérstöku pekkingu er í samræmi við kröfu tilskipunar 2006/43/EB. Eins er í tilskipuninni nú sérstaklega tekið fram að í heild skuli nefndarmenn í hafa yfir að ráða hæfni sem viðkemur geiranum sem endurskoðaða einingin starfar í. Af pessu orðalagi er ljóst að aðrir nefndarmenn en hinn sérfróði kunna að búa yfir mismunandi pekkingu sem nýtist í störf- 
um endurskoðunarnefndar pannig að hún í heild sinni geti sinnt starfi sínu með fullnægjandi hætti. Til samanburðar má vísa til 52. gr. laga um fjármálafyrirtæki nr. 161/2002 par sem segir að samsetning stjórnar fjármálafyrirtækis skuli vera með peim hætti að stjórnin búi sameiginlega yfir fullnægjandi pekkingu, hæfni og reynslu til að skilja pá starfsemi sem viðkomandi fjármálafyrirtæki stundar, p.m.t. helstu áhættupætti. Rökin að baki pessu eru pau að slík samsetning stjórnar sé til pess fallin að auka fjölbreytileika og koma í veg fyrir hjarðhugsun pannig að stjórn sé betur til pess fallin að sinna eftirlitshlutverki sínu (Frumvarp til laga um breytingu á lögum um fjármálafyrirtæki).

Að pví er varðar pá kröfu að einn nefndarmanna að lágmarki hafi staðgóða pekkingu og reynslu á sviði reikningsskila eða endurskoðunar er раð аð segja að hún felur í sér að sé endurskoðunarnefnd skipuð eingöngu stjórnarmönnum purfi a.m.k. einn stjórnarmanna að uppfylla pessar kröfur. Í pessu sambandi má nefna að áður en dönskum lögum um endurskoðendur var breytt árið 2016 (Lov om ændring af revisorloven og forskellige andre love nr. 631/2016) gátu aðeins stjórnarmenn eða nefndarmenn í fulltrúanefnd tekið sæti í endurskoðunarnefnd. Eftir pær breytingar sem gerðar voru á árinu 2016 er gert ráð fyrir að hluthafafundur geti skipað formann og aðra nefndarmenn í endurskoðunarnefnd enda er pess ekki lengur krafist að peir komi úr hópi stjórnarmanna einingarinnar. Í greinargerð með frumvarpi til laganna kom fram að breytingin væri til pess fallin að auðvelda skipun endurskoðunarnefnda par sem einstaklingar með sérstaka pekkingu á reikningsskilum og endurskoðun pyrftu ekki lengur, að ópörfu, að taka sæti í stjórnum eininga til pess að uppfylla skilyrði eldri danskra laga par um (Lovforslag nr. L 146, 201516, bls. 24-25).

\section{Endurskoðunarnefndir í einingum tengdum al- mannahagsmunum á Íslandi}

\subsection{Einingar tengdar almannahagsmunum}

Eins og áður er rakið teljast einingar tengdar almannahagsmunum á Íslandi vera lífeyrissjóðir, lánastofnanir, vátryggingafélög og útgefendur skráðra verðbréfa. Hinn 1 . september 2020 var 21 lífeyrissjóður, 12 lánastofnanir og 11 vátryggingafélög með starfsleyfi (Fjármálaeftirlitið, á.d.). Pá voru 19 hlutafélög með skráð hlutabréf og 52 íslenskir útgefendur skuldabréfa í kauphöll Nasdaq Iceland, fyrir utan íslenska ríkið (Nasdaq Iceland, á.d.-a; á.d.-b). Af skráðum hlutafélögum voru fimm lánastofnanir og vátryggingafélög og af útgefendum skráđra skuldabréfa voru 13 lánastofnanir, vátryggingafélög eða skráð hlutafélög. Alls voru pví a.m.k. 97 aðilar sem töldust einingar tengdar almannahagsmunum hinn 1. september 2020. Hér er ekki horft til íslenskra lögaðila sem hafa verðbréf sín skráð á skipulegum verðbréfamarkaði innan EES eða EFTA en utan Íslands og er pví samantektin ekki tæmandi hvað pá aðila varðar.

Á meðal útgefenda skráðra skuldabréfa voru 11 fagfjárfestasjóðir sem voru í rekstri fimm mismunandi rekstrarfélaga verðbréfasjóða. Reikningsskil fagfjárfestasjóðs sem er í rekstri rekstrarfélags falla undir B-hluta reikningsskila rekstrarfélagsins og eru á ábyrgð stjórnar pess. Rekstrarfélag sem rekur fagfjárfestasjóð með útgefin skráð skuldabréf getur pví einnig talist eining tengd almannahagsmunum. Að meðtöldum pessum fimm rekstrarfélögum voru pví allt að 102 aðilar sem töldust einingar tengdar almannahagsmunum.

Tafla 3 í viðauka sýnir upplýsingar um hverja einingu tengda almannahagsmunum, hvort við hana starfi endurskoðunarnefnd, fjöldi nefndarmanna, fjöldi nefndarmanna utan stjórnar og hvort formaður nefndarinnar sé utan stjórnar. Upplýsingarnar eru unnar upp úr heimasíðum, ársreikningum og stjórnarháttayfirlýsingum eininganna og miðast við 1. september 2020. Í fáeinum tilvikum var ekki unnt að afla upplýsinga um skipan nefndarinnar pann dag og er pá byggt á nýjustu fáanlegu upplýsingum og gert ráo fyrir að skipan nefndarinnar sé óbreytt. İ nokkrum tilvikum sitja varamenn stjórnar í endurskoðunarnefnd og eru peir flokkaðir sem nefndarmenn úr stjórn. Pá sitja stjórnarmenn 
móðurfélags í nokkrum nefndum en hér teljast peir nefndarmenn utan stjórnar.

Tafla 1 sýnir samantekt á endurskoðunarnefndum eininganna og nefndarmönnum utan stjórnar. Einingunum er skipt í framangreinda flokka en útgefendum skráðra verðbréfa er jafnframt skipt nánar niður í flokka, annars vegar í útgefendur skráðra hlutabréfa og skráðra skuldabréfa og hins vegar er útgefendum skráðra skuldabréfa skipt nánar niður eftir starfsemi eða félagsformi.

Tafla 1. Endurskoðunarnefndir í einingum tengdum almannahagsmunum.

Fyrsti dálkurinn sýnir flokk eininga, annar fjölda eininga tengdra almannahagsmunum í flokknum og priðji fjölda eininga með endurskoðunarnefnd. Næstu fimm dálkar sýna fjölda nefnda með engan, einn, tvo prjá og fjóra nefndarmenn utan stjórnar og síðasti dálkurinn sýnir fjölda nefnda með formann utan stjórnar.

Heimild: Heimasíður, ársreikningar og stjórnarháttayfirlýsingar eininganna hinn 1. september 2020.

\begin{tabular}{l|cc|ccccc|c}
\hline & \multicolumn{2}{|c|}{ Fjöldi eininga } & \multicolumn{3}{c|}{ Nefndarmenn utan stjórnar } & \multicolumn{2}{c}{$\begin{array}{c}\text { For- } \\
\text { maður }\end{array}$} \\
\hline Lífeyrissjóðir & Alls & Með nefnd & 0 & 1 & 2 & 3 & 4 & 13 \\
Lánastofnanir & 21 & 21 & 1 & 8 & 10 & 2 & 0 & 3 \\
Vátryggingafélög & 12 & 12 & 2 & 5 & 4 & 1 & 0 & 6 \\
Skráð hlutafélög* & 11 & 8 & 0 & 1 & 3 & 4 & 0 & 6 \\
Útgefendur skráðra skuldabréfa: & 14 & 14 & 1 & 13 & 0 & 0 & 0 & 6 \\
- Fagfjárfestasjóðir & & & & & & & & \\
- Rekstrarfélög verðbréfasjóða & 11 & 0 & 0 & 0 & 0 & 0 & 0 & 0 \\
- Samlagshlutafélög & 5 & 2 & 2 & 0 & 0 & 0 & 0 & 0 \\
- Sveitarfélög & 3 & 2 & 0 & 0 & 1 & 1 & 0 & 1 \\
- Ađrir útgefendur** & 12 & 1 & 0 & 0 & 0 & 1 & 0 & 1 \\
\hline Alls & 13 & 10 & 1 & 4 & 2 & 1 & 2 & 7 \\
\hline
\end{tabular}

* Inniheldur ekki lánastofnanir og vátryggingafélög

** Inniheldur ekki lánastofnanir, vátryggingafélög og skráð hlutafélög

\subsection{Einingar án endurskoðunarnefndar}

Af töflu 1 sést að af 102 einingum tengdum almannahagsmunum voru 70 með endurskoðunarnefnd svo 32 einingar höfðu ekki starfandi nefnd. Af peim voru 11 fagfjárfestasjóðir og 11 sveitarfélög með útgefin skráð skuldabréf. Prjú vátryggingafélög starfrækja ekki endurskoðunarnefnd en í hverju slíku tilviki er um að ræða dótturfélag annars vátryggingafélags sem starfrækir endurskoðunarnefnd. Prjú rekstrarfélög verðbréfasjóða starfrækja ekki endurskoðunarnefnd en í öllum peim tilvikum er einnig um dótturfélög að ræða par sem endurskoðunarnefnd er starfandi við móðurfélagið. Eitt samlagshlutafélag og prír aðrir skuldabréfaútgefendur starfrækja ekki endurskoðunarnefnd og er par annars vegar um að ræða tvö dótturfélög skráðra fasteignafélaga og hins vegar einkahlutafélag um rekstur skólahúsnæðis í eigu nokkurra sveitarfélaga.

Engar undanpáguheimildir frá starfrækslu endurskoðunarnefndar við einingu tengda almannahagsmunum eru í íslenskum lögum. Eins og áður er rakið er í 39. gr. tilskipunar 2006/43/EB aðildarríkjum hins vegar veitt heimild til að veita tilteknum einingum undanpágu frá starfrækslu nefndarinnar eða (a) dótturfélögum félaga sem uppfylla ákvæði greinarinnar á samstæðugrundvelli, (b) verðbréfasjóðum og sérhæfðum sjóðum, (c) félögum sem hafa pann eina tilgang að gefa út eignatryggð verðbréf og (d) óskráðum lánastofnunum sem hafa ekki gefið út skuldabréf yfir 10 milljónum evra. Stór hluti íslensku eininganna sem ekki starfrækja endurskoðunarnefnd fellur undir pessi undanpáguákvæði. Pá falla einnig fjölmargar íslenskar einingar sem starfrækja endurskoðunarnefnd undir undanpáguákvæðin. Engin augljós rök hníga að pví að innleiða ekki í íslensk lög pessar undanpáguheimildir sem 39. gr. tilskipunarinnar heimilar aðildarríkjunum að gera.

Sem dæmi eru meðal lánastofnana fjórir sparisjóðir sem hver um sig starfrækir endur- 
skoðunarnefnd. Enginn peirra er með skráð hlutabréf eða útgefin skuldabréf yfir 10 milljónum evra og falla peir pví undir d-lið undanpáguákvæðis tilskipunarinnar. Innleiðing samsvarandi undanpáguheimildar í íslensk lög myndi aflétta skyldu til starfrækslu endurskoðunarnefndar af sjóðunum.

Sveitarfélög með útgefin skráð skuldabréf teljast einingar tengdar almannahagsmunum. Engar beinar undanpáguheimildir frá starfrækslu endurskoðunarnefndar eru fyrir sveitarfélög, hvorki í íslenskum lögum né ESB-rétti. Á Íslandi eru tólf sveitarfélög með útgefin skráð skuldabréf en aðeins eitt peirra starfrækir endurskoðunarnefnd, Reykjavíkurborg. Í ljósi pess er fullt tilefni til að kveða nánar á um skyldu sveitarfélaga með útgefin skráð skuldabréf til starfrækslu endurskoðunarnefndar.

\subsection{Samsetning endurskoðunarnefnda}

Endurskoðunarnefnd skal skipuð að lágmarki premur mönnum. Allar nefndirnar 70 uppfylla petta skilyrði en tíu nefndir eru skipaðar fjórum mönnum. Í heild sitja pví 220 menn í endurskoðunarnefndum eininga tengdra almannahagsmunum.

Í aðeins sjö einingum af peim 70 sem hafa starfandi endurskoðunarnefnd er nefndin eingöngu skipuð stjórnarmönnum. Par er um að ræða Frjálsa lífeyrissjóðinn, Íslandsbanka, Borgun, Marel, Landsbréf, Stefni og HS Veitur. Í öllum öðrum nefndum er a.m.k. einn nefndarmaður utan stjórnar, par af einn í 31 nefnd, tveir í 20 nefndum, prír í tíu nefndum og fjórir í tveimur nefndum. I tólf einingum er nefndin skipuð premur eða fjórum aðilum utan stjórnar. Í níu einingum par af er nefndin eingöngu skipuð aðilum utan stjórnar, p.e. stjórn einingarinnar á engan fulltrúa í nefndinni. Heildarfjöldi nefndarmanna utan stjórnar er 109 eða rétt tæplega helmingur allra nefndarmanna.

Af peim 63 nefndum sem skipuð er a.m.k. einum utan stjórnar sinnir nefndarmaður utan stjórnar formennsku í a.m.k. 37 nefndum eða í stórum meirihluta nefndanna. Ekki var unnt að afla upplýsinga um formennsku í átta nefndum til viðbótar.

Í íslenskri einingu tengdri almannahagsmunum er pví algengast að endurskoðunarnefnd sé skipuð premur mönnum, par af einum eða tveimur nefndarmönnum utan stjórnar, og að formaður nefndarinnar sé utan stjórnar.

\subsection{Skipun nefndarmanna}

Í lögum um ársreikninga er stjórn einingarinnar falin ábyrgð á skipun nefndarinnar. Nefndarmenn endurskoðunarnefnda eru yfirleitt skipaðir af stjórn en í nokkrum tilvikum virðist nefndin pó vera skipuð af eigendum eða stjórn móðurfélags.

Hjá Reykjavíkurborg starfar endurskoðunarnefnd á vegum borgarstjórnar. Hún er skipuð fjórum fulltrúum sem eru allir skipaðir af borgarstjórn en par af er einn fulltrúi skipaður á grundvelli tilnefningar stjórnar Orkuveitu Reykjavíkur. Hinn 1. september 2020 var nefndin skipuð premur aðilum utan borgarstjórnar en einn nefndarmaður var varaborgarfulltrúi. Nefndin starfar einnig sem endurskoðunarnefnd tveggja félaga í eigu borgarinnar, Orkuveitu Reykjavíkur og Félagsbústaða hf. (Reykjavíkurborg, á.d.). Endurskoðunarnefndir Orkuveitunnar og Félagsbústaða eru pví í raun ekki skipaðar af stjórn félaganna heldur eiganda peirra. Nefndir pessara félaga eru jafnframt einu nefndirnar sem eru skipaðar fjórum mönnum sem allir eru utan stjórnar.

Greiðslumiðlunin Hringur ehf. er dótturfélag Hörpu tónlistar- og ráðstefnuhúss ohf. Eini tilgangur félagsins er að gefa út skuldabréf vegna byggingar tónlistar- og ráđstefnuhússins Hörpu og annast mánaðarlegar afborganir af peim. Skuldabréfin eru skráð og pví telst félagið eining tengd almannahagsmunum. Við félagið starfar endurskoðunarnefnd sem jafnframt er endurskoðunarnefnd Hörpu. Nefndin var skipuð af stjórn Hörpu og telst pví ekki formlega skipuð af stjórn félagsins heldur eiganda pess eða stjórn móðurfélags.

Öll fjögur íslensku vátryggingafélögin, Sjóvá, TM, VÍS og Vörður, eru með starfandi endurskoðunarnefnd sem er skipuð af stjórn félaganna. Hvert peirra á einnig líftryggingafélag og í premur félaganna, Sjóvá, VÍS og Verði, starfar endurskoðunarnefnd vátrygg- 
ingafélagsins einnig sem endurskoðunarnefnd liftryggingafélagsins. Nefndirnar eru skipaðar af stjórn en í sumum tilvikum er kveðið á að samráð skuli haft við stjórn líftryggingafélagsins um skipun nefndarinnar. Endurskoðunarnefndir líftryggingafélaganna eru pví í raun skipaðar af eigendum félaganna eða stjórn móðurfélags.

Í ljósi pess að lög um ársreikninga fela stjórn ábyrgð á skipun endurskoðunarnefndar getur leikið vafi á pví hvort ofangreindar nefndir teljist rétt skipaðar. Tilskipun 2006/43/ EB heimilar sérstaklega að nefndarmenn séu skipaðir að hluta eða öllu leyti af eigendum einingarinnar en pað er ekki heimilað með skýrum hætti í íslenskum lögum. Í 1. mgr. 39. gr. tilskipunarinnar er svo sérstaklega kveðið á um að endurskoðunarnefnd skuli annað hvort vera sjálfstæð nefnd eða undirnefnd stjórnar. Æskilegt væri að heimild væri fyrir pví í lögum að eigendur tilnefni nefndarmenn í endurskoðunarnefnd og að nefndin geti hvort sem er verið sjálfstæð nefnd eða undirnefnd stjórnar.

\subsection{Nefndarmenn utan stjórnar skipaðir af stjórn}

Af framangreindu er ljóst að pað er almenn venja á Íslandi að stjórn skipi einn eða fleiri aðila utan stjórnar í endurskoðunarnefnd. Раð fyrirkomulag er ekki æskilegt af ýmsum ástæðum. Í fyrsta lagi dregur pað úr sjálfstæði nefndarmanna utan stjórnar gagnvart peim nefndarmönnum sem koma úr röðum stjórnarmanna. Ef störf utanaðkomandi nefndarmanns eru ekki að skapi stjórnar getur hún skipað annan í hans stað, án aðkomu eigenda. Í öðru lagi er umboð slíkra aðila annað en stjórnarmanna í nefndinni; stjórnarmenn sækja umboð sitt til eigenda en nefndarmenn utan stjórnar sem skipaðir eru af stjórn sitja par í umboði stjórnarinnar. Að pessu leyti má jafna stöðu peirra við stöðu utanaðkomandi aðila sem stjórn ræður sér til ráðgjafar. Í priðja lagi er hlutverk endurskoðunarnefndar hluti af hlutverki stjórnar. Með pví að skipa einn eða fleiri utanaðkomandi aðila er stjórn pví í raun að útvista að hluta pví eftirlitshlutverki sem eigendur hafa falið henni. Í fjórða og síðasta lagi búa nefndarmenn utan stjórnar ekki yfir sömu innsýn í málefni einingarinnar og stjórnarmenn, eins og fjallað er um í dönskum leiðbeiningum um stjórnarhætti fyrirtækja (Komitéen for god selskabsledelse, 2020, gr. 3.4.2).

Раð getur verið viðeigandi að endurskoðunarnefnd sé að hluta til eða öllu leyti skipuð nefndarmönnum utan stjórnar t.d. ef svo ber við að sérfræðipekkingu skortir meðal stjórnarmanna eða ef vafi leikur á óhæði stjórnarmanna gagnvart félaginu. Til að auka sjálfstæði slíkra nefndarmanna og skýra umboð peirra og ábyrgð er pó æskilegt að peir séu tilnefndir á sama hátt og aðrir stjórnarmenn en séu ekki skipaðir af stjórn. Til að svo megi verði er nauðsynlegt að skýrt sé kveðið á um pað í lögum að nefndarmenn geti verið tilnefndir af eigendum. Petta er í samræmi við ákvæði tilskipunar 2006/43/EB um að nefndarmenn komi úr röðum stjórnarmanna eða eftirlitsstjórnarmanna eða séu tilnefndir af hluthafafundi eða hliðstæðum vettvangi.

Tilnefning nefndarmanna utan stjórnar ætti pó að teljast til undantekninga og ætti nefndin eingöngu að vera skipuð stjórnarmönnum ef pess er kostur enda eru verkefni endurskoðunarnefndar hluti af verkefnum stjórnar og á ábyrgð hennar. Eðlilegt verður einnig að teljast að stjórn einingar sem varðar almannahagsmuni sé pannig skipuð að í henni sitji einstaklingar sem uppfylla pær kröfur um óhæði og sérfræðipekkingu sem gerðar eru til nefndarmanna í endurskoðunarnefnd.

\section{Niðurstöður}

Í greininni er fjallað um pær lagareglur sem gilda um endurskoðunarnefndir sem einingum tengdum almannahagsmunum er skylt að hafa. Megináherslan er lögð á lýsa skipun, óhæði og hæfniskröfum til nefndarmanna eins og pær birtast í IX. kafla A í lögum um ársreikninga (108. gr. a - d). Pá er einnig fjallað um undanpáguheimildir í reglunum. Reglunum sem settar voru með lögum nr. 80/2008, um breyting á lögum um ársreikninga, með hliðsjón af tilskipun 2006/43/EB, hefur ekki verið breytt, en í millitíðinni hefur tilskipuninni verið breytt með tilskipun 2014/56/EB. Með hinni nýju tilskipun hafa ýmis ákvæði 
verið nánar skýrð og öðrum nýmælum aukið við. Eins og hér er rakið hafa reglur um endurskoðunarnefndir reynst vandskýrðar. Pá virðist framkvæmdin hér á landi ekki fyllilega hafa verið í samræmi við ákvæði tilskipunarinnar sem pær byggjast á. Petta verður að hafa í huga pegar reglurnar verða teknar til skoðunar með hliðsjón af ákvæðum tilskipunar 2014/56/EB og fenginni reynslu.

Í 3. kafla er fjallað um lagaumhverfi endurskoðunarnefnda, sér í lagi hvað felist í peim orðum laga um ársreikninga að meirihluti nefndarmanna í endurskoðunarnefnd skuli vera óháður einingunni. Við mat í peim efnum má horfa til tilmæla framkvæmdastjórnarinnar (2005/162/EB) og Leiðbeininga um stjórnarhætti fyrirtækja. Engu að síður verður mat á óhæði að byggjast á efnislegu mati í hverju tilviki fyrir sig með hliðsjón af aðstæðum hér á landi. Engin ástæða er til að ætla að stjórnarmenn geti ekki, vegna setu sinnar í stjórn, talist óháðir nefndarmenn eins og hreyft var í umræðunni á sínum tíma.

Einnig var í 3. kafla tekin til skoðunar tilskipun 2014/56/ESB, sem breytti tilskipun 2006/43/EB, en með henni hafa verkefni endurskoðunarnefndar verið skýrð nánar og peim fjölgað. Рá er orðuð sú krafa, sem er nýmæli, að nefndarmenn í endurskoðunarnefnd skuli í heild hafa yfir að ráða hæfni sem viðkemur geiranum sem einingin starfar í. Einnig er par nýmæli heimild til handa aðildarríkjunum að víkja frá meginreglunni um að meirihluti nefndarmanna í endurskoðunarnefndum skuli vera óháður einingunni ef peir eru allir stjórnarmenn í einingunni. Pessi heimild vekur athygli í ljósi peirrar kröfu sem gerð hefur verið um óhæði nefndarmanna. Nú er pess aðeins krafist að meirihluti nefndarmanna sé óháður ef í nefndinni sitja nefndarmenn utan stjórnar, sem skipaðir eru á hluthafafundi. Pannig hafa Danir t.d. lögfest pessa undantekningu frá óhæði en leiðbeiningar um stjórnarhætti par í landi gera pó áfram ráð fyrir að meirihluti nefndarmanna sé óháður.

Í kafla 4.2 er pess getið аð við ýmsar einingar tengdar almannahagsmunum starfi engar endurskoðunarnefndir prátt fyrir skýra lagaskyldu. Eins og par er rakið er um priðjungur af einingunum án endurskoðunarnefndar, par á meðal sveitarfélög, fagfjárfestasjóðir, rekstrafélög verðbréfasjóða og líftryggingafélög. Ástæður pess eru mismunandi, svo sem pegar móðurfélag starfrækir endurskoðunarnefnd. Pótt skiljanlegt sé að umræddar einingar séu án endurskoðunarnefndar heimila íslensk lög, hvað sem pví líður, engar undantekningar, pótt tilskipun 2006/43/EB geri ráð fyrir undanpágum. Ekki er unnt að túlka íslensk lög svo, með hliðsjón af tilskipuninni, að pau heimili undantekningar, enda er hún lágmarkstilskipun sem heimilar aðildarríkjunum að gera meiri kröfur en gerðar eru í tilskipuninni. Með hliðsjón af pessu er full ástæða til að taka til athugunar hvort lögfesta beri pær undantekningar sem fram koma í tilskipuninni, svo sem um dótturfélög, verðbréfasjóði, útgefendur eignatryggðra verðbréfa og smáar lánastofnanir. Hins vegar er pess að geta að tilskipunin gerir ekki ráð fyrir undantekningum varðandi sveitarfélög. Par af leiðandi ber peim að hafa endurskoðunarnefnd ef pau eru útgefendur verðbréfa á markaði. Í ljósi framkvæmdarinnar kynni að vera ástæða til að árétta pað í sjálfum lagatextanum.

Í kafla 4.3 er rakið að um helmingur nefndarmanna í endurskoðunarnefndum hér á landi situr ekki í stjórn einingarinnar. Af tilskipun 2006/43/EB og tilmælum framkvæmdastjórnarinnar sem tilskipunin vísar til, má ráđa að endurskoðunarnefnd skal almennt skipuð stjórnarmönnum í félagsstjórn (eða fulltrúanefnd) sé tekið mið af íslenskum félagarétti. Einnig er sá möguleiki orðaður í tilskipuninni að skipa megi endurskoðunarnefnd fulltrúum sem eru tilnefndir á hluthafafundi einingarinnar. Pennan síðari möguleika verður að skilja svo að einstaklingar, sem ekki sitja í félagsstjórn, geti pví aðeins tekið sæti í endurskoðunarnefnd að hluthafafundur standi að peirri skipun. Af pessu leiðir að sá háttur að félagsstjórn skipi endurskoðunarnefnd nefndarmönnum utan stjórnar, eins og rakið er í kafla 4.5, samrýmist ekki orðalagi tilskipunarinnar, hvort heldur fyrir eða eftir breytingarnar með tilskipun 2014/56/ESB. Pess eru pó dæmi hér á landi að eigendur skipi endurskoðunarnefnd eins og greinir í kafla 4.4 en án pess að fyrir pví sé skýr stoð í íslenskum lögum.

Með hliðsjón af peirri framkvæmd sem tíðkast hefur hér á landi væri skynsamlegt að 
lögfesta heimild til að skipa nefndarmenn utan stjórnar í endurskoðunarnefnd á hluthafafundi einingarinnar (eða hliðstæðum vettvangi) eins og miðað er við í tilskipuninni. Samhliða pví að treysta lagalegan grundvöll nefndarmanna utan stjórnar væri um leið leitast við tryggja sjálfstæði peirra gagnvart stjórninni. Pá væri rétt að kveða svo á að nefndarmenn utan stjórnar væru við störf sín bundnir sömu lagaskyldum og nefndarmenn sem jafnframt eiga sæti í stjórn einingarinnar, t.d. hvað varðar pagnarskyldu og aðrar trúnaðarskyldur. Fallast má að rök geti hnigið til pess að skipa nefndarmenn utan stjórnar í einhverjum tilvikum. Svo dæmi sé tekið var við breytingar á reglum um endurskoðunarnefndir í Danmörku árið 2016 vísað til pess að heimildin auðveldaði skipun nefnda par sem einstaklingar með sérstaka pekkingu á reikningsskilum og endurskoðun pyrftu ekki lengur, að ópörfu, að taka sæti í stjórnum eininga til pess að uppfylla skilyrði eldri danskra laga par um. Á hinn bóginn birtist sú afstaða í dönsku leiðbeiningunum um stjórnarhætti аð í endurskoðunarnefnd taki aðeins sæti stjórnarmenn, en ekki nefndarmenn utan stjórnar, par sem hinir síðarnefndu búi ekki yfir sömu innsýn í málefni félagsins og stjórnarmenn (Komitéen for god selskabsledelse, 2020). Рað sjónarmið á ekki síður við á Íslandi.

\section{Heimildir}

Aktiebolagslag nr. 551/2005.

Andersen, P.K. (2019). Aktie- og anpartsselskabsret (14. útg.). Osló: Jurist- og Økonomforbundets Forlag.

Bunch, L. og Whitt, S.C. (2018). Selskabsloven med kommentarer (3. útg.). Kaupmannahöfn: Karnov Group.

Einar Guðbjartsson. (2011). Endurskoðunarnefnd. Um hugtakið „óháður einingunni“. Í Ingjaldur Hannibalsson (ritstjóri), Rannsóknir í félagsvísindum XII. Viðskiptafræðideild, 74-80. Reykjavík: Félagsvísindastofnun Háskóla Î́slands.

Einar Guðbjartsson og Jón Snorri Snorrason. (2013). Endurskoðunarnefndir: Starfsumhverfi og umfang. Í Ingjaldur Hannibalsson (ritstjóri), Rannsóknir i félagsvísindum XIV. Viðskiptafræðideild, 1-12. Reykjavík: Félagsvísindastofnun Háskóla Íslands.

Einar Guðbjartsson og Jón Snorri Snorrason. (2017). Umhverfi og starfsemi endurskoðunarnefnda - bakgrunnur nefndarmanna og traust á fjárhagsupplýsingum. Tímarit um viðskipti og efnahagsmál, 14(1), $25-42$.

Einar Guðbjartsson, Eypór Ívar Jónsson og Jón Snorri Snorrason. (2018). Endurskoðunarnefndir: Samsetning og góðir stjórnarhættir. Tímarit um viðskipti og efnahagsmál, 15(2), 73-96.

Elmar Hallgríms Hallgrímsson. (2011). Starfshættir endurskoðunarnefnda. Staðan á Íslandi með hliðsjón af stjórnarháttum fyrirtækja. Meistaraprófsritgerð við Viðskiptafræðideild Háskóla Íslands.

Evrópupingið og ráðið. (2008). Tilskipun Evrópupingsins og ráðsins 2006/43/EB frá 17. maí um lögboðna endurskoðun ársreikninga og samstæðureikninga, um breytingu á tilskipunum ráðsins 78/660/EBE og 83/349/ EBE og um niðurfellingu á tilskipun ráđsins 84/253/EBE. EES-viðbætir við Stjórnartíðindi Evrópusambandsins Nr. 78/175.

Evrópupingið og ráđið. (2014). Tilskipun Evrópupingsins og ráðsins 2014/56/ESB frá 16. apríl 2014 um breytingu á tilskipun 2006/43/EB um lögboðna endurskoðun ársreikninga og samstæðureikningsskila. EES-viðbætir við Stjórnartíðindi Evrópusambandsins Nr. 31/65.

Fjármálaeftirlitið. (2011, 9. júní). Drög að leiðbeinandi tilmælum um skipan og störf endurskoðunarnefnda eftirlitsskyldra aðila. Umræðuskjal nr. 6/2011.

Fjármálaeftirlitið. (á.d.). Eftirlitsskyldir aðilar. Sótt 1. september 2010 af https://www.fme.is/eftirlit/eftirlitsskyld-starfsemi/eftirlitsskyldir-adilar/

Framkvæmdastjórn ESB. (2010). Green Paper. Audit policy: Lessons from the Crisis. Brussel: European Commission.

Frumvarp til laga um endurskoðendur. Pskj. 827, 526. mál. Vefútgáfa Alpingistíðinda, slóð: https://www.althingi.is/altext/135/s/0827.html [Sótt 1. september 2020].

Frumvarp til laga um breyting á lögum nr. 3/2006, um ársreikninga, með síðari breytingum. Pskj. 828, 527. mál. Vefútgáfa Alpingistíðinda, slóð: https://www.althingi.is/altext/135/s/0828.html [Sótt 1. september 2020].

Frumvarp til laga um breytingu á lögum um fjármálafyrirtæki, nr. 161/2002, með síðari breytingum (starfsleyfi, áhættustýring, stórar áhættuskuldbindingar, starfskjör, eignarhlutir, eiginfjáraukar o.fl.). Pskj. 990, 571. mál. Vefútgáfa Alpingistíðinda, slóð: https://www.althingi.is/altext/144/s/0990.html [Sótt 1. september 2020].

Grundmann, S. og Glasow, F. (2012). European Company Law: Organization, Finance and Capital Markets (2. útg.). Cambridge: Intersertia.

Hallur Símonarson. (2008, ágúst). Orkuveita Reykjavíkur. Stjórnsýsluúttekt. Reykjavík: Reykjavíkurborg. Innri endurskoðun.

Kollegiet för svensk bolagsstyrning. (2019, 1. desember). Svensk kod för bolagsstyrning. Stokkhólmur: Höfundur. 
Komitéen for god selskabsledelse. (2020, 2. desember). Anbefalinger for god selskabsledelse. Kaupmannahöfn: Höfundur.

Lovforslag nr. L 146. Folketinget 2015-16.

Lov om aksjeselskaper nr. 45/1997.

Lov om godkendte revisorer og revisionsvirksomheder (revisorloven) nr. 468/2008.

Lov om ændring af revisorloven og forskellige andre love nr. 631/2016.

Lög um hlutafélög nr. 2/1995.

Lög um fjármálafyrirtæki nr. 161/2002.

Lög um ársreikninga nr. 3/2006, með síðari breytingum.

Lög um endurskoðendur nr. 79/2008.

Lög um breyting á lögum nr. 3/2006 um ársreikninga nr. 80/2008.

Lög um endurskoðendur og endurskoðun nr. 94/2019.

Nasdaq Iceland. (á.d.-a). Hlutabréf. Sótt 1. september 2020 af http://www.nasdaqomxnordic.com/hlutabref

Nasdaq Iceland. (á.d.-b). Skuldabréf - Ísland. Sótt 1. september 2020 af http://www.nasdaqomxnordic.com/ skuldabref/island

Norsk utvalg for eierstyring og selskapsledelse. (2018, 17. október). Norsk anbefaling. Eierstyring og selskapsledelse (9. útg.). Osló: Höfundur.

Páll Hreinsson. (2014). Samræmd EES-túlkun. Tímarit lögfræðinga, 64(3), 273-307.

Ráð Evrópubandalaganna. (1984). Tilskipun 84/253/EBE um löggildingu einstaklinga sem falið er að annast löggilta endurskoðun bókhaldsgagna.

Reglugerð Evrópupingsins og ráðsins (ESB) nr. 537/2014 frá 16. apríl 2014 um sérstakar kröfur í tengslum við lögboðna endurskoðun á einingum sem tengjast almannahagsmunum og niðurfellingu á ákvörðun framkvæmdastjórnarinnar 2005/909/EB. EES-viðbætir við Stjórnartíðindi Evrópusambandsins Nr. 31/29.

Reykjavíkurborg. (á.d.). Endurskoðunarnefnd. Sótt 1. september 2020 af https://reykjavik.is/radognefndir/endurskodunarnefnd

Róbert R. Spanó (2019). Túlkun lagaákvæða (2. útg.). Reykjavík: Bókaútgáfan Codex.

Sarbanes-Oxley Act of 2002, PL 107-204, 116 Stat 745.

Skýrsla nefndar um málefni endurskoðenda. (2011, janúar).

Stefán Már Stefánsson. (2013). Hlutafélagaréttur. Reykjavík: Hið íslenska bókmenntafélag.

Stjórnartíðindi Evrópusambandsins. (2005). Tilmæli framkvæmdastjórnarinnar frá 15. febrúar 2005 (2005/162/EB) um hlutverk stjórnarmanna, sem eru ekki framkvæmdastjórar, eða eftirlitsstjórnarmanna í skrádum félögum svo og um stjórnarnefndir (eftirlitsstjórnarnefndir) félaga. L 52, 25.2.2005.

Verslunarrád Íslands, Kauphöll Íslands og Samtök atvinnulífsins. (2004). Leiðbeiningar um stjórnarhætti fyrirtækja. Reykjavík: Höfundur.

Viðskiptaráð Íslands, Nasdaq Iceland og Samtök atvinnulífsins. (2015). Leiðbeiningar um stjórnarhætti fyrirtækja (5. útg.). Reykjavík: Höfundur. 


\section{Viðauki}

Tafla 2. Samsetning endurskoðunarnefnda tíu stærstu fyrirtækja priggja Norðurlanda.

Fyrsti dálkurinn sýnir nafn fyrirtækisins, annar fjölda stjórnarmanna, sá priðji fjölda nefndarmanna í endurskoðunarnefnd og sá fjórði fjölda nefndarmanna utan stjórna. Fyrir hvert land er samantekt sem sýnir meðalfjölda stjórnarmanna, nefndarmanna og nefndarmanna utan stjórnar.

Heimild: Heimasíður og ársreikningar fyrirtækjanna 22. júlí 2021.

\begin{tabular}{|c|c|c|c|}
\hline & Stjórnarmenn & Nefndarmenn & Utan stjórnar \\
\hline Noregur: (10) & 10,3 & 3,6 & 0 \\
\hline Equinor & 11 & 5 & 0 \\
\hline Norsk Hydro asa & 9 & 4 & 0 \\
\hline Telenor asa & 10 & 4 & 0 \\
\hline Aker asa & 8 & 3 & 0 \\
\hline Orkla asa & 11 & 3 & 0 \\
\hline Aker Solutions & 11 & 4 & 0 \\
\hline TotalEnergies in Norway & 13 & 4 & 0 \\
\hline Yara International asa & 10 & 3 & 0 \\
\hline Kommunal Landspensjonskasse & 8 & 3 & 0 \\
\hline NorgesGruppen asa & 12 & 3 & 0 \\
\hline Svípjóð: (10) & 13,1 & 3,6 & 0 \\
\hline Nordea & 14 & 4 & 0 \\
\hline Volvo & 16 & 3 & 0 \\
\hline SEB Group & 13 & 4 & 0 \\
\hline Svenska Handelsbanken & 13 & 3 & 0 \\
\hline Swedbank & 11 & 5 & 0 \\
\hline $\mathrm{H} \& \mathrm{M}$ & 14 & 3 & 0 \\
\hline Telia Company & 11 & 3 & 0 \\
\hline Atlas Copco & 11 & 4 & 0 \\
\hline Ericsson & 16 & 4 & 0 \\
\hline Essity & 12 & 3 & 0 \\
\hline Danmörk: (10) & 10,9 & 3,6 & 0 \\
\hline A.P. Møller-Maersk & 10 & 4 & 0 \\
\hline Danske Bank & 11 & 3 & 0 \\
\hline Novo Nordisk & 12 & 5 & 0 \\
\hline Carlsberg Group & 15 & 4 & 0 \\
\hline Vestas & 12 & 3 & 0 \\
\hline TDC Group & 11 & 2 & 0 \\
\hline Nokian Tyres & 9 & 4 & 0 \\
\hline Novozymes & 11 & 3 & 0 \\
\hline Coloplast & 9 & 4 & 0 \\
\hline Jyske Bank & 9 & 4 & 0 \\
\hline
\end{tabular}


Tafla 3. Samsetning endurskoðunarnefnda í einingum tengdum almannahagsmunum.

Fyrsti dálkurinn sýnir nafn einingarinnar, annar hvort við eininguna sé endurskoðunarnefnd, sá priðji fjölda nefndarmanna, sá fjórði fjölda nefndarmanna utan stjórnar og sá fimmti hvort formaður nefndarinnar sé utan stjórnar. Fyrir hvern flokk er samantekt sem sýnir fjölda eininga með nefnd, meðalfjölda nefndarmanna og nefndarmanna utan stjórnar og fjölda nefnda sem eru með formann utan stjórnar.

Heimild: Heimasíður, ársreikningar og stjórnarháttayfirlýsingar eininganna hinn 1. september 2020.

\begin{tabular}{|c|c|c|c|c|}
\hline & Með nefnd & $\begin{array}{c}\text { Nefndar- } \\
\text { menn }\end{array}$ & $\begin{array}{c}\text { Utan } \\
\text { stjórnar }\end{array}$ & Formaður \\
\hline Lífeyrissjóðir: (21) & 21 & 3,0 & 1,6 & 13 \\
\hline Almenni lífeyrissjóðurinn & Já & 3 & 2 & Já \\
\hline Birta lífeyrissjóður & Já & 3 & 2 & Já \\
\hline Brú lífeyrissjóður starfsmanna sveitarfélaga & Já & 3 & 2 & Já \\
\hline Eftirlaunasjóður F.Í.A. & Já & 3 & 3 & Já \\
\hline Festa - lífeyrissjóður & Já & 3 & 1 & Já \\
\hline Frjálsi lífeyrissjóðurinn & Já & 3 & 0 & Nei \\
\hline Gildi - lífeyrissjóður & Já & 3 & 2 & Já \\
\hline Íslenski lífeyrissjóðurinn & Já & 3 & 1 & Nei \\
\hline Lífeyrissjóður bankamanna & Já & 3 & 2 & Já \\
\hline Lífeyrissjóður bænda & Já & 3 & 2 & Nei \\
\hline Lífeyrissjóður Rangæinga & Já & 3 & 2 & ? \\
\hline Lífeyrissjóður starfsmanna Akureyrarbæjar & Já & 3 & 1 & ? \\
\hline Lífeyrissjóður starfsmanna Búnaðarbanka Íslands hf. & Já & 3 & 1 & Nei \\
\hline Lífeyrissjóður starfsmanna Reykjavíkurborgar & Já & 3 & 2 & Já \\
\hline Lífeyrissjóður starfsmanna ríkisins & Já & 3 & 1 & Já \\
\hline Lífeyrissjóður Tannlæknafélags Ísl. & Já & 3 & 2 & Já \\
\hline Lífsverk lífeyrissjóður & Já & 3 & 3 & Já \\
\hline Lífeyrissjóður verslunarmanna & Já & 3 & 2 & Nei \\
\hline Lífeyrissjóður Vestmannaeyja & Já & 3 & 1 & Já \\
\hline Stapi lífeyrissjóður & Já & 3 & 1 & ? \\
\hline Söfnunarsjóður lífeyrisréttinda & Já & 3 & 1 & Já \\
\hline Lánastofnanir: (12) & 12 & 3,2 & 1,3 & 3 \\
\hline Arion banki hf. & Já & 4 & 1 & Nei \\
\hline Íslandsbanki hf. & Já & 3 & 0 & Nei \\
\hline Kvika banki hf. & Já & 3 & 1 & Nei \\
\hline Landsbankinn hf. & Já & 4 & 1 & Nei \\
\hline Sparisjóður Austurlands hf. & Já & 3 & 1 & Nei \\
\hline Sparisjóður Höfðhverfinga ses. & Já & 3 & 3 & Já \\
\hline Sparisjóður Strandamanna ses. & Já & 3 & 2 & Nei \\
\hline Sparisjóður Suður-Pingeyinga ses. & Já & 3 & 1 & Nei \\
\hline Borgun hf. & Já & 3 & 0 & Nei \\
\hline Byggðastofnun & Já & 3 & 2 & Já \\
\hline Lánasjóður sveitarfélaga ohf. & Já & 3 & 2 & Nei \\
\hline Lykill fjármögnun hf. & Já & 3 & 2 & Já \\
\hline Vátryggingafélög: (11) & 8 & 3,5 & 2,4 & 6 \\
\hline Íslensk endurtrygging hf. & Nei & & & \\
\hline Líftryggingafélag Íslands hf. & Já & 4 & 3 & ? \\
\hline TM líftryggingar hf. & Nei & & & \\
\hline
\end{tabular}




\begin{tabular}{|c|c|c|c|c|}
\hline & Með nefnd & $\begin{array}{l}\text { Nefndar- } \\
\text { menn }\end{array}$ & $\begin{array}{l}\text { Utan } \\
\text { stjórnar }\end{array}$ & Formaður \\
\hline Náttúruhamfaratrygging Íslands & Já & 3 & 2 & Já \\
\hline Sjóvá-Almennar líftryggingar hf. & Já & 3 & 3 & Já \\
\hline Sjóvá-Almennar tryggingar hf. & Já & 3 & 3 & Já \\
\hline TM hf. & Já & 3 & 1 & Já \\
\hline TM Tryggingar hf. & Nei & & & \\
\hline Vátryggingafélag Íslands hf. & Já & 4 & 2 & Já \\
\hline Vörður lifftryggingar hf. & Já & 4 & 3 & Já \\
\hline Vörður tryggingar hf. & Já & 4 & 2 & Nei \\
\hline Skráð hlutafélög: (14) & 14 & 3,1 & 0,9 & 6 \\
\hline Brim hf. & Já & 3 & 1 & Já \\
\hline Eik fasteignafélag hf. & Já & 3 & 1 & Nei \\
\hline Eimskipafélag Íslands hf. & Já & 3 & 1 & $?$ \\
\hline Festi hf. & Já & 3 & 1 & Já \\
\hline Hagar hf. & Já & 3 & 1 & Já \\
\hline Icelandair Group hf. & Já & 3 & 1 & Já \\
\hline Icelandic Seafood International hf. & Já & 3 & 1 & Nei \\
\hline Marel hf. & Já & 4 & 0 & Nei \\
\hline Origo hf. & Já & 3 & 1 & Nei \\
\hline Reginn hf. & Já & 3 & 1 & Já \\
\hline Reitir fasteignafélag hf. & Já & 3 & 1 & Nei \\
\hline Síminn hf. & Já & 3 & 1 & Já \\
\hline Skeljungur hf. & Já & 3 & 1 & $?$ \\
\hline Sýn hf. & Já & 3 & 1 & Nei \\
\hline Fagfjárfestasjóðir: (11) & 0 & 0 & 0 & 0 \\
\hline AAM GLEQ3 & Nei & & & \\
\hline GAMMA: Méllon & Nei & & & \\
\hline SIV Fjármögnun & Nei & & & \\
\hline Fagfjárfestasjóðurinn ÍsH & Nei & & & \\
\hline Fagfjárfestasjóðurinn Landsbréf-BÚS I & Nei & & & \\
\hline KLS, fagfjárfestasjóður & Nei & & & \\
\hline REG 1 fagfjárfestasjóður & Nei & & & \\
\hline REG 2 Smáralind, fagfjárfestasjóður & Nei & & & \\
\hline REG3A fjármögnun & Nei & & & \\
\hline Veðskuldabréfasjóðurinn Virðing & Nei & & & \\
\hline Veðskuldabréfasjóður ÍV & Nei & & & \\
\hline Rekstrarfélög verðbréfasjóða: (5) & 2 & 3,0 & 0,0 & 0 \\
\hline GAMMA Capital Management hf. & Nei & & & \\
\hline ÍV sjóðir hf. & Nei & & & \\
\hline Júpíter rekstrarfélag hf. & Nei & & & \\
\hline Landsbréf hf. & Já & 3 & 0 & Nei \\
\hline Stefnir hf. & Já & 3 & 0 & Nei \\
\hline Samlagshlutafélög: (3) & 2 & 3,0 & 2,5 & 1 \\
\hline Alda Credit Fund slhf. & Já & 3 & 3 & Já \\
\hline FÍ Fasteignafélag slhf. & Já & 3 & 2 & $?$ \\
\hline Veðskuld slhf. & Nei & & & \\
\hline
\end{tabular}




\begin{tabular}{|c|c|c|c|c|}
\hline & Með nefnd & $\begin{array}{l}\text { Nefndar- } \\
\text { menn }\end{array}$ & $\begin{array}{l}\text { Utan } \\
\text { stjórnar }\end{array}$ & Formaður \\
\hline Sveitarfélög: (12) & 1 & 4,0 & 3,0 & 1 \\
\hline Akureyrarkaupstaður & Nei & & & \\
\hline Sveitarfélagið Árborg & Nei & & & \\
\hline Fljótsdalshérað & Nei & & & \\
\hline Garðabær & Nei & & & \\
\hline Fjarðabyggð & Nei & & & \\
\hline Hafnarfjarðarkaupstaður & Nei & & & \\
\hline Kópavogsbær & Nei & & & \\
\hline Mosfellsbær & Nei & & & \\
\hline Norðurping & Nei & & & \\
\hline Rangárping ytra & Nei & & & \\
\hline Reykjavíkurborg & Já & 4 & 3 & Já \\
\hline Vestmannaeyjabær & Nei & & & \\
\hline Aðrir skuldabréfaútgefendur: (13) & 10 & 3,2 & 1,9 & 7 \\
\hline Almenna leigufélagið ehf. & Já & 3 & 1 & Já \\
\hline Félagsbústaðir hf. & Já & 4 & 4 & Já \\
\hline Greiðslumiðlunin Hringur ehf. & Já & 3 & 3 & Já \\
\hline Heimavellir hf. & Já & 3 & 2 & Nei \\
\hline HS Veitur hf. & Já & 3 & 0 & Nei \\
\hline Orkuveita Reykjavíkur & Já & 4 & 4 & Já \\
\hline ÍL-sjóður & Já & 3 & 2 & Já \\
\hline Íslandshótel hf. & Já & 3 & 1 & $?$ \\
\hline Jeratún ehf. & Nei & & & \\
\hline Norðurslóð 4 ehf. & Nei & & & \\
\hline Landfestar ehf. & Nei & & & \\
\hline Landsnet hf. & Já & 3 & 1 & Já \\
\hline Rarik ohf. & Já & 3 & 1 & Já \\
\hline
\end{tabular}


